\title{
Linear Growth as a Function of Age at Onset of Puberty and Sex Steroid Dosage: Therapeutic Implications*
}

\author{
JEAN-PIERRE BOURGUIGNON ${ }^{\dagger}$ \\ Department of Pediatrics and Radioimmunoassay Laboratory, University of Liège, CHU \\ Sart-Tilman, B-4000 Liège, Belgium
}

I. Introduction

II. The Hormonal Constituents of the Pubertal Growth Spurt
A. Gonadal sex steroids
B. GH
C. Insulin-like growth factor-I (IGF-I)
D. Adrenal sex steroids
E. Summary

III. The Auxological Parameters Used to Evaluate Growth at Puberty and to Predict its Importance for Final Height

IV. Role of Sex Steroid Dosage
A. Estrogens

B. Androgens

V. Role of Age at Onset of Puberty
A. Girls
B. Boys

VI. Therapeutic Implications

\section{Introduction}

$\mathrm{P}$ UBERTY plays a dual role in growth: height velocity is markedly accelerated while the rate of skeletal maturation is also increased with resultant fusion of epiphyseal cartilages. Thus, puberty can be considered as a growth-promoting event as well as the final heightlimiting process. This concept is illustrated by early exposure to sex steroids such as occurs in central precocious puberty or congenital adrenal hyperplasia. These conditions accelerate growth but result in short adult height (1-6).

The basic question addressed in this paper is how hormonal changes at puberty and the age of their occurrence influence growth rate and adult height. This query has practical implications including timing and dosage of sex steroid replacement therapy in hypogonadal patients and the use of GnRH agonist therapy in patients with precocious puberty or short stature. These issues may have profound social import since numerous (mostly

\footnotetext{
* This work was supported in part by Grant 3.4574 .87 from Belgian Fonds de la Recherche Scientifique Médicale.

$\dagger$ To whom requests for reprints may be addressed.
}

uncharted) psychological aspects of adolescence may be related to stature and the timing of sexual development.

The following sections will review 1) the hormonal constituents of the pubertal spurt, 2) the auxological parameters important for evaluating growth at puberty and for predicting its importance for final height, 3 ) the role of sex steroid dosage, 4) the role of age at onset of puberty and, 5) some therapeutic implications.

\section{The Hormonal Constituents of the Pubertal Growth Spurt}

Several hormonal factors may interact to determine the pubertal growth spurt: $\mathrm{GH}$, insulin-like growth factor I (IGF-I), and sex steroids (androgens, estrogens) of gonadal and adrenal origins. The permissive role of thyroid hormones and the interactions of insulin and nutrition will not be discussed. The aim of this section is to examine the respective roles of GH, IGF-I, and sex steroids in eliciting the pubertal growth spurt.

\section{A. Gonadal sex steroids}

Growth-promoting effects independent of GH. In both sexes, the role of gonadal steroids is obvious from the remarkable acceleration of linear growth which occurs at the time of sexual maturation (Fig. 1a) whether that event is early, normal, or delayed (7). In the absence of normal GH and IGF-I secretion, gonadal steroids have limited growth-promoting effects (Fig. 1b). This is suggested by the subnormal increase of the growth rate in hypopituitary boys treated with testosterone before GH therapy was available (8).

Additional evidence of the effects of sex steroids in the absence of GH action is obtained in patients with Laron dwarfism (9) who present with high GH and very low IGF-I and who attain an adult height of 110 to $140 \mathrm{~cm}$. Among eight of these patients followed longitudinally throughout puberty (10), three girls did not show any significant growth spurt. In contrast, in three boys and two girls who grew at a mean rate of $2.9 \mathrm{~cm} / \mathrm{yr}$ before 

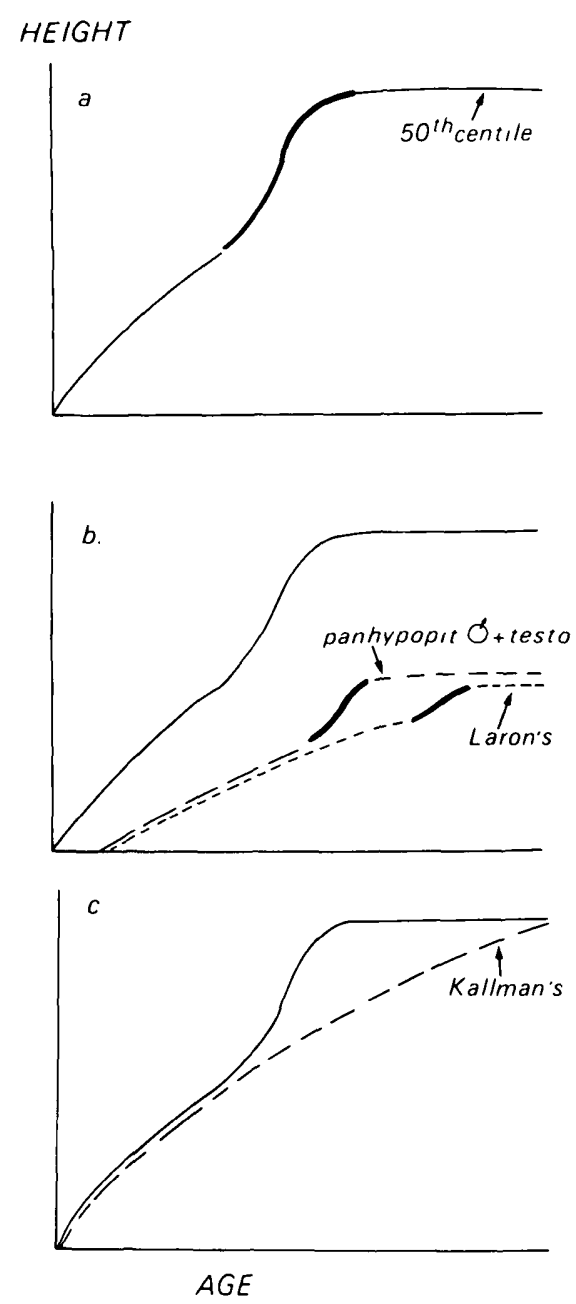

FIG. 1. Schematic representation of height in relation to age in normal subjects (a), in the absence of normal GH or IGF-I secretion (b), and in the absence of gonadal sex steroids (c). Dark portions of the curves indicate the pubertal growth spurt.

puberty, height velocity increased to $6.5 \mathrm{~cm} / \mathrm{yr}$ during sexual maturation.

These observations (Fig. 1b) suggest that sex steroids, particularly androgens, may have a direct growth effect independent of GH and IGF-I. This hypothesis is supported by recent observations of a stimulatory effect of sex steroids on rabbit growth cartilage in vitro (11). However, the concept of a GH-independent acceleration of growth by sex steroids cannot be established in the clinical situations described above since it is almost impossible to demonstrate the complete absence of any GH IGF-I effect in those patients. Nonetheless, the acceleration of growth, if any, caused by sex steroids in the absence of normal GH IGF-I is minimal when compared to the normal pubertal spurt.

Sex specificity of gonadal steroid effects on growth. The pubertal growth spurt is generally attributed to androgens in boys and estrogens in girls. While, in females, estradiol is clearly the sex steroid associated with pubertal growth, it is possible that, in males, the growthpromoting effects of androgens are partly mediated through their transformation into estrogens. This hypothesis is supported by the following lines of evidence.

In Fig. 2 are illustrated the mean plasma levels of estradiol and testosterone (calculated from Refs. 12-17) in relation to the pubertal growth spurt in both sexes (18). The interpretation of such data on plasma sex steroid levels must be made with caution in the absence of longitudinal observations of integrated night-time and day-time levels in relation to bone age. Also, we do not know the threshold plasma levels of estradiol and testosterone required for growth stimulation. Nonetheless, it is interesting to note (Fig. 2) that a sharp increase in testosterone secretion occurs quite late during puberty. Therefore, at the time of maximal height velocity, plasma testosterone levels in boys and girls are, respectively, $18 \%$ and $44 \%$ compared to concentrations achieved at 15-16 yr. In contrast, estradiol increases earlier than testosterone in both sexes. At peak height velocity, estradiol levels in boys and girls represent $75 \%$ and $72 \%$, respectively, of the concentration achieved at 15-16 yr.

In both sexes, aromatase has been found in several extraglandular locations such as muscle and adipose tissue (19) and it has been shown that only small amounts of estrogens are produced by the testes. Most of the estrogen is formed peripherally in male subjects $(20,21)$. In addition to bone marrow (22), conversion of androgen precursors into estrogens could occur in the cartilage although we still lack evidence supporting such hypothesis. An indirect argument for the role of estrogens in longitudinal bone growth in the male is the presence of estrogen receptors in osteoblast-like cells (23, 24).

A physiological role for estrogens in the male pubertal growth spurt is also supported by the correlation between integrated GH concentrations and plasma estrogen concentrations (25) while no correlation is seen with testosterone (25-27). In addition, at puberty in both sexes, the rising plasma levels of IGF-I are correlated to total estradiol plasma levels (28) or free estradiol concentrations but not with testosterone (25). However, it is possible that circadian and episodic fluctuations in plasma sex steroid levels have biased those studies.

A more direct demonstration of a role for estrogens in the male pubertal growth spurt has been provided by Caruso-Nicoletti et al. (29). These authors have shown that a 4-day infusion of estradiol to five prepubertal or early pubertal boys results in a 2.6-, 2.0-, and 1.8-fold increase in ulnar growth velocity when estradiol plasma levels are 10,16 , and $96 \mathrm{pg} / \mathrm{ml}$, respectively (29). Higher concentrations of estradiol than those derived physiologically from testosterone do not induce any significant 


\author{
○- \\ $\square$ ESTRADIOL $\left(E_{2}\right)$, TESTOSTERONE (T) PLASMA LEVELS
}
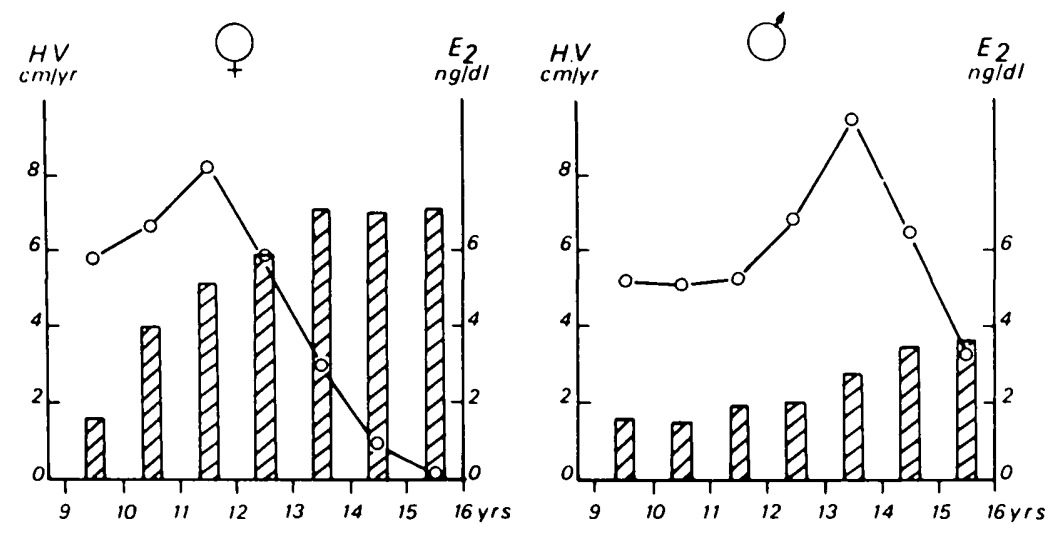

FIG. 2. Relationship between the pubertal growth spurt and the plasma levels of estradiol and testosterone in both sexes.

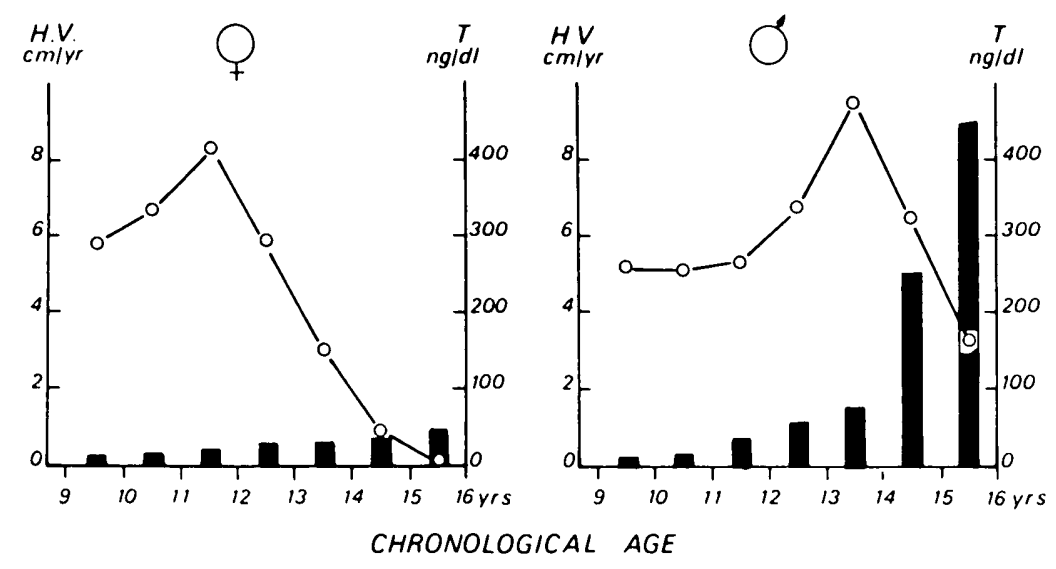

growth effect (30). These data indicate that, in male subjects, estrogens may have a biphasic effect similar to that observed in girls.

A convincing demonstration of the role of endogenous or synthetic estrogens in males has been provided by Zachmann et al. in nine patients with the androgen insensitivity syndrome (31). These phenotypic females with an XY karyotype achieve a pubertal growth spurt quantitatively and chronologically similar to normal girls, with plasma estradiol concentrations within or above the normal range for pubertal males. The observation of accelerated growth in prepubertal boys with gynecomastia caused by increased testicular (32) or peripheral (33) aromatase activity also suggests a mediatory role for estrogens in male growth. Finally, a contribution of estrogens to pubertal growth in boys is suggested by the significant reduction of height velocity to $6 \mathrm{~cm} / \mathrm{yr}$ in three patients with testotoxicosis treated using the aromatase inhibitor testolactone together with the antiandrogen spironolactone while growth rate was $12 \mathrm{~cm} / \mathrm{yr}$ using spironolactone as a single therapy (58).

While several observations support the role of estradiol in the male pubertal growth spurt, there is no clear evidence of a physiological role for androgens in the female pubertal growth spurt. Recently, Rosenfield (34) showed that long-acting testosterone $28 \mathrm{mg} / \mathrm{m}^{2} \cdot \mathrm{month}$ given for 6 months to five Turner patients with pubertal bone ages (10.6-12.8 yr) resulted in a 2 -fold increase in height velocity. This effect may have involved testosterone conversion into estradiol. However, it is likely that androgens are themselves growth-promotors in girls since treatment of patients with gonadal dysgenesis (35, 36 ) or hypopituitary girls (37) using nonaromatizable androgenic steroids (oxandrolone and norethandrolone) induces a significant acceleration of the growth rate.

The growth-promoting action of androgens and estrogens is at least partly explained by their stimulatory effect on integrated $\mathrm{GH}$ concentrations $(8,26,38)$. In contrast, oxandrolone does not affect $24 \mathrm{~h}$ GH secretion and plasma IGF-I levels (39). In a more recent study, a significant but modest $(+20 \%)$ increase in plasma IGF-I levels has been reported after 3 months of oxandrolone therapy in boys with constitutional delay of puberty (40). Such an effect does not occur in prepubertal boys and could be related to the increase in $\mathrm{GH}$ secretion or in testosterone production at the beginning of puberty and during its progression (41). However, a physiological role for endogenous androgens in the female pubertal growth 
spurt cannot be inferred from the therapeutic effects of oxandrolone.

Interactions of $\mathrm{GH}$ with sex steroid secretion. Some authors have examined the question whether or not sex steroid secretion is influenced by possible interaction of GH with the pituitary-gonadal system. In hypopituitary patients, the gonadotropin responses to synthetic GnRH are not different before and during GH therapy (42). This suggests that GH does not interact with FSH and LH secretion at the pituitary level.

The interactions of GH at the gonadal level have been investigated through sex steroid responses to human CG (hCG). Early studies by Rivarola et al. (43) and by Zachmann (44) in 1972 suggested a stimulatory effect of GH on testosterone secretion after prolonged hCG administration in three postpubertal patients. More recently, in prepubertal hypopituitary boys, Zipf et al. (45) and Maes et al. (46) did not observe any significant change in testosterone responsiveness to HCG after, respectively, 4 and 3 months of GH therapy. However, in similar patients, Kulin et al. (47) found the testosterone response to hCG to increase after a longer period of GH therapy ranging from 6 to 12 months. These latter authors were unable to observe any GH-related change in estradiol secretion induced by hCG in somatotropindeficient girls (48).

The decreased phallic size in some newborns with GH deficiency (49) suggests a peripheral or intratesticular interaction of $\mathrm{GH}$ with sex steroid production or action during intrauterine life. There is no clinical data to support a significant interaction at puberty. Also, evidence is lacking of a major role for GH in priming pituitary-gonadal maturation or in maintaining its functional level in adults. However, rapid onset of puberty has been observed within a few months after initiation of hGH therapy in hypopituitary patients (50). We lack detailed studies on pituitary-gonadal functions after withdrawal of GH replacement therapy in patients with isolated GH deficiency.

While the paracrine role of IGF-I in the gonads is well established, its regulation by pituitary GH has not been fully elucidated. Experimental data indicate that the gonadotropins stimulate IGF-I production by cultured porcine granulosa cells (51) and IGF-II gene expression in human granulosa cells (52). In addition, testicular IGF-I receptors may be induced by hCG and, conversely, there is an up-regulation of hCG receptors by IGF-I (53). Recent data suggest that GH may also be involved in the control of ovarian IGF-I secretion (54).

\section{B. $G H$}

Growth effects of GH in the absence of sex steroids. In patients with sex steroid deficiency and normal GH secretion (Fig. 1c), no pubertal growth spurt occurs. Patients with congenital hypogonadism (anorchia or Kallman's syndrome) have a normal pattern of prepubertal growth (55). However, no obvious pubertal growth spurt occurs in $\mathrm{GH}$-treated boys with gonadotropin deficiency unless sex steroids are administered $(56,57)$.

A so-called "normal" adult height is attained by hypogonadal patients with isolated gonadotropin deficiency not treated with sex steroids before epiphyseal fusion $(58,59)$. This indicates that, on the whole, adult stature is not affected by the absence of sex steroids. However, body proportions are not normal in those patients. This is because the adolescent spurt in sitting height is predominantly controlled by sex steroids and relatively independent of GH, while the spurt of legs is GH-dependent (56). Therefore, the apparently normal expression of growth potential in the absence of sex steroids results from an excess in leg growth relative to growth of the trunk.

Interactions of sex steroids with GH secretion. Numerous authors have shown that sex steroids modulate $\mathrm{GH}$ secretion. While early studies were focused on $\mathrm{GH}$ response to pharmacological tests, more recent observations have examined the amplitude, the frequency, and the integrated concentrations of intermittent GH secretion.

An early study of testosterone effect on GH response to insulin-induced hypoglycemia or arginine in boys with constitutional delay of puberty was reported by Martin et al. in 1968 (60). These authors confirmed their earlier observation by showing that 21 of 22 boys, with constitutional delay of puberty and a subnormal GH responsiveness, normalized their GH levels after a 5-day course of testosterone propionate therapy, $25 \mathrm{mg} /$ day (61). In 4 patients with anorchia, Illig and Prader (62) found an impaired GH response to insulin-induced hypoglycemia which was normalized by a 2- to 3-month testosterone therapy while the same treatment did not affect $\mathrm{GH}$ responsiveness in a $\mathrm{GH}$-deficient patient.

In a cohort of 105 patients with constitutional growth delay, Gourmelen et al. (63) reported that $23 \%$ had a reduced $\mathrm{GH}$ response to ornithine or insulin-induced hypoglycemia. After spontaneous puberty was begun, GH response was normalized, confirming early observations on the increase of GH response to arginine- or insulininduced hypoglycemia during normal puberty $(64,65)$. Estrogens are also effective in increasing GH secretion after provocative stimuli as shown by studies on the effects of short-term administration of relatively high estrogen doses (66-71).

The study of integrated GH concentrations has provided information on the physiological interactions between sex steroids and GH. In several studies, integrated concentrations of $\mathrm{GH}$ were found to be higher in pubertal 
subjects of both sexes than those seen before puberty and during adulthood $(25,38,72-75)$. In girls with central precocious puberty, integrated concentrations of $\mathrm{GH}$ are increased 1.5 times over prepubertal values (76) and reduced to 0.5 times the pretreatment level after 6 months of treatment with a GnRH agonist (77). In boys with constitutional delay of puberty $(39,78)$ and in males with hypogonadotropic hypogonadism (79), integrated GH concentrations are increased up to 4.3 times after chronic testosterone therapy.

During spontaneous puberty, the priming effect of sex steroids on integrated GH concentrations is dependent on an increased amplitude of GH secretory episodes while frequency is not affected $(25,80)$. In addition, testosterone administration to patients with delayed puberty or hypogonadism results in a 2.1 - to 3 -fold increase of GH pulse amplitude whereas pulse frequency is unchanged $(39,79,80)$.

Some observations do not corroborate a stimulatory effect of sex steroids on GH secretion. Spiliotis et al. (81) did not observe any significant change in integrated concentrations of GH between prepuberty and puberty, in accordance with a previous report by Thompson et al. (26) and with some of the observations by Drop et al. (82). These different results may be explained by the heterogeneity of patients studied; that is, the administration of sex steroids or the occurrence of spontaneous puberty will increase GH secretion in patients with constitutional delay of puberty but not in those having any form of GH deficiency.

Contribution of $G H$ to the pubertal growth spurt. In patients with isolated GH deficiency, the pubertal growth spurt is severely reduced, which contributes in part to the shortened adult stature $(83,84)$. This observation unequivocally establishes $\mathrm{GH}$ as a prerequisite to the growth spurt. However, the threshold level of GH secretion required to obtain a pubertal spurt may be low since a moderate but significant acceleration of the growth rate $(6.8 \mathrm{~cm} / \mathrm{yr})$ is seen in girls with central precocious puberty and deficient $\mathrm{GH}$ response $(<5 \mu \mathrm{g} / \mathrm{ml})$ to provocative stimuli (114). Also, it is unclear whether the sex steroid-induced rise in $\mathrm{GH}$ secretion is a requirement for achieving the spurt. In fact, a pubertal growth spurt occurs under constant GH replacement in hypopituitary patients $(56,57,85-90)$. However, in such individuals, the mean peak height velocity during spontaneous and testosterone-induced puberty is 7.6 and $7.3 \mathrm{~cm}$, respectively, a consistently lower gain than the average peak of $10.3 \mathrm{~cm} / \mathrm{yr}(91,92)$ found in normal boys. Noteworthy, the peak height velocity is physiologically lower in late maturers (18) who are close to patients with untreated isolated GH deficiency in terms of timing of onset of puberty. Also, the lower peak height velocity in those patients may result from the nonphysiological schedule of $\mathrm{GH}$ administration which was 3 times a week in the above studies.

An alternative explanation is the absence of a pubertyrelated increase in $\mathrm{GH}$ dosage. This hypothesis is not supported by the data of Job et al. (93) in patients with isolated GH deficiency. These authors obtained mean total pubertal height gains of 21.0 and $14.3 \mathrm{~cm}$ in hypopituitary boys and girls, respectively, while the normal spurts are 28 and $25 \mathrm{~cm}$. They found no relationship between pubertal height gain and hGH dosage varying between 12 and $26 \mathrm{IU} / \mathrm{kg} \cdot \mathrm{yr}$. As pointed out by Job et al., these variations of GH dosage may be too small since there is an exponential relationship between growth rate and hGH dosage $(94,95)$. Still, a critical factor is the discrepancy between $\mathrm{GH}$ administration 3 times a week and physiological GH secretory pulses several times a day since the so-called replacement doses of $\mathrm{GH}$ are well above the normal production rate of $\mathrm{GH}$.

\section{Somatomedin C/IGF-I}

Plasma IGF-I: origin and role in growth. Since Salmon and Daughaday (96) described the growth-promoting action of $\mathrm{GH}$ as dependent on an intermediate factor identified later as somatomedin C or IGF-I, evidence has accumulated to establish the $\mathrm{GH}$-dependent production and release of IGF-I as a fundamental mechanism in the endocrine control of growth (97-99). Studies attempting to localize the site of IGF-I production failed to identify a major and exclusive source for the pool of IGF-I circulating in plasma, although it is generally agreed that, in man, at least half the circulating IGF-I comes from the liver. The existence of different IGF-I sources is consistent with the observation of IGF production by several tissues from human fetuses $(100,101)$ and adult fibroblasts $(102,103)$, indicating its possible paracrine or autocrine role as well as endocrine function.

In the rat, a direct action of $\mathrm{GH}$ on bone growth has been shown by Isaksson et al. (104). This effect appears to involve IGF-I production locally by the growth plate under the control of GH as shown recently in that species (105). To date, it is unclear how and to what extent circulating IGF-I and IGF-I synthesized locally in the cartilage contribute to skeletal growth. Other important methodological and physiological questions arise from the existence of certain IGF-I binding proteins which also make interpretation of IGF-I circulating levels difficult. The unsaturated IGF-I binding protein level (106) and its radioimmunoassayable low molecular weight form (107) are high in conditions associated with low plasma IGF-I levels, such as hypopituitarism, while the binding protein is lowered by a treatment using $\mathrm{GH}$ which restores normal IGF-I secretion. This indicates 
that IGF-I may regulate negatively the production of some fractions of its binding protein while others are positively regulated.

In hypopituitary or short-stature patients, growth response to GH therapy is not correlated with plasma IGFI levels (108-110). A similar dissociation between growth rate and plasma IGF-I levels is found in late normal puberty after the growth spurt $(28,111,112)$ and during $\mathrm{GnRH}$ agonist therapy in central precocious puberty (77, 113), while before therapy, the growth rate and the plasma IGF-I levels are positively correlated. (114). These results are consistent with local production of IGF-I in the cartilage. In those cases, plasma levels of IGF-I represent more likely an index of total production, not necessarily a requirement for longitudinal growth.

Interactions of sex steroids with IGF-I. At puberty, there is a characteristic rise in plasma concentrations of IGFI $(28,115-117)$. Detailed studies of this phenomenon have shown that this increase in IGF-I plasma levels occurs $1 \mathrm{yr}$ earlier in girls than in boys (112) and is correlated to plasma estradiol levels in both sexes (28, $31)$. In children with central precocious puberty, IGF-I shows a premature rise $(76,77)$ which can also be induced by treating hypogonadal patients with androgens $(39,79$, $118)$ as well as with estrogens (119-121). Thus, experimental and clinical evidence indicates that increased sex steroid secretion is associated with stimulation of $\mathrm{GH}$ and IGF-I and accelerated rates of growth and of bone maturation (Table 1).

The growth-promoting effect of sex steroids, however, does not necessarily require an increase in plasma concentrations of IGF-I. In hypopituitary boys under GH replacement therapy at a constant dosage, testosterone accelerates growth without concomitant stimulation of

TABLE 1. Interactions between sex steroids, IGF-I, and growth in different conditions resulting in increased sex steroid level

\begin{tabular}{lcccc}
\hline & $\begin{array}{c}\text { GH } \\
\text { secretion }\end{array}$ & $\begin{array}{c}\text { IGF-I } \\
\text { plasma } \\
\text { level }\end{array}$ & $\begin{array}{c}\text { Growth } \\
\text { rate }\end{array}$ & $\begin{array}{c}\text { Bone } \\
\text { maturation } \\
\text { rate }\end{array}$ \\
\hline $\begin{array}{l}\text { Normal puberty (early } \\
\text { stage) }\end{array}$ & $\nearrow$ & $\nearrow$ & $\nearrow$ & $\nearrow$ \\
$\begin{array}{l}\text { Central precocious pu- } \\
\text { berty }\end{array}$ & $\nearrow$ & $\nearrow$ & $\nearrow$ & $\nearrow$ \\
$\begin{array}{l}\text { Sex steroid therapy in } \\
\text { hypogonadal pa- } \\
\text { tients }\end{array}$ & $\nearrow$ & $\nearrow$ & $\nearrow$ & $\nearrow$ \\
$\begin{array}{l}\text { Low-dose estrogen } \\
\text { therapy in gonadal } \\
\text { dysgenesis }\end{array}$ & & $=$ & & \\
$\begin{array}{l}\text { Testosterone therapy } \\
\text { of GH-treated boys }\end{array}$ & $=$ & $=$ & $\nearrow$ & $\nearrow$ \\
$\begin{array}{l}\text { Normal puberty (late } \\
\text { stage) }\end{array}$ & $\nearrow$ & $\nearrow$ & $\searrow$ & \\
$\begin{array}{l}\text { Estrogen therapy of } \\
\text { tall girls }\end{array}$ & $\nearrow$ & $\searrow$ & $\nearrow$ & $\nearrow$ \\
\hline
\end{tabular}

plasma IGF-I concentrations $(111,118,122)$. A similar finding is present in patients with gonadal dysgenesis treated with low-dose estrogens $(120,123,124)$. In these conditions and in others such as the late stages of normal puberty and high-dose estrogen treatment in tall girls, variations of plasma IGF-I levels do not parallel the changes in plasma sex steroid concentrations (Table 1). Some of those discrepancies may be explained by a doserelated biphasic effect of estrogens $(28,120)$.

In African pygmies, an illustration of the role of IGFI at puberty has been proposed by Merimee et al. (125, 126). They reported that these subjects develop normal sex characteristics and pubertal plasma levels of sex steroids but show no pubertal growth spurt and end up with a mean adult stature of $144.0 \mathrm{~cm}$. The proposed explanation is that plasma levels of IGF-I that are normal before puberty only increase to $35-49 \%$ of the concentrations seen during normal puberty. In fact, careful examination of the original growth data (127) indicates that linear growth accelerates at puberty in pygmies; the apparent absence of a pubertal spurt results quite likely from the use of pooled cross-sectional observations (Tanner J., personal communication). Reevaluation of auxological data will be necessary for correlating IGF-I levels and quantitated parameters of pubertal growth.

Are the effects of sex steroids on IGF-I secretion mediated by GH? Such a mechanism is strongly suggested by the absence of changes in IGF-I secretion after sex steroid administration to hypopituitary patients under a constant regimen of GH therapy $(111,118,122)$. Also, observations during normal or precocious puberty show a direct relationship between the increase of IGFI and integrated GH concentrations $(25,76)$, both changes being reversed during $\mathrm{GnRH}$ agonist therapy (77).

Some stimulatory effects of sex steroids on IGF-I may be independent of GH since increased IGF-I levels with unchanged GH secretion have been observed during low dose estrogen or oxandrolone therapy in gonadal dysgenesis patients $(36,128)$. The unchanged plasma IGF-I levels reported by others during similar treatments $(35$, $123,124)$ do not exclude a local stimulation of IGF-I by sex steroids in the cartilage. In other conditions, a dissociation between IGF-I and GH secretion is observed. In acromegalic patients or in adolescent girls with tall stature, estrogen therapy at relatively high dosages does not affect IGF-I levels (70) or reduces IGF-I concentrations $(66,68,69,129)$ while $\mathrm{GH}$ secretion is elevated in those conditions.

\section{Adrenal sex steroids}

A possible role for adrenal androgens in the control of growth arose from the short adult height observed in 
men and women with untreated congenital adrenal hyperplasia. In this condition, high testosterone levels are well established in addition to increased $\Delta_{4}$-androstenedione and dehydroepiandrosterone (DHEA) secretion. From the data of Thamdrup (1), Styne et al. (3), JonesKlingensmith et al. (4), Urban et al. (5), and Di MartinoNardi et al. (6), mean adult height observed in 9 male patients and 39 female patients never treated before adulthood was $153.8 \mathrm{~cm}$ and $150.6 \mathrm{~cm}$, respectively. This is an obvious, but not striking, reduction in adult stature, given the prolonged period of androgen excess.

A stimulatory role for adrenal androgens in the control of growth in normal children was suggested by the concomitant onset of adrenarche $(12,13)$ and an increase in height velocity observed in prepubertal children around 7-9 yr of age (130). In contrast, in hypopituitary boys and girls, or other patients with absent adrenarche, physiological replacement using long-acting injectable DHEA or its short-acting oral form (DHEA-sulfate) for 1 to 2 yr failed to elicit any significant increase in height velocity (131-133). Thus, an excess of adrenal androgens and testosterone has been shown to accelerate linear growth and bone maturation. Although these hormones cause premature growth arrest and short stature in pathological conditions, there is no evidence for a physiological role of adrenal androgens in the control of normal growth.'

\section{E. Summary: hormonal constituents of the pubertal growth spurt}

In Fig. 3 are represented the three pathways of sex steroid interaction with growth at puberty.

1. Sex steroids may themselves have a growth-promoting action independent of GH and IGF-I, but this seems to be a rather minor contribution to the pubertal growth spurt.

2. The major mechanism is the increased amplitude of GH secretory episodes in the presence of sex steroids, estradiol being the putative mediator of this effect. $\mathrm{GH}$ in turn stimulates IGF-I production, accounting for or reflecting the increased growth rate.

3. In the absence of GH increase, another possible mechanism is the direct interaction of sex steroids with IGF-I secretion. As detailed in the following section, this effect is biphasic for estrogens since only low doses are stimulatory while high doses are inhibitory for IGF-I.

\footnotetext{
'Editor's comment: The failure of DHEA administration to increase height velocity does not exclude the possibility that adrenal androstenedione may promote prepubertal bone growth by conversion to estrogen. DHEA is a much less efficient precursor of peripheral estrogen synthesis than is androstenedione (see Ref. 183).
}

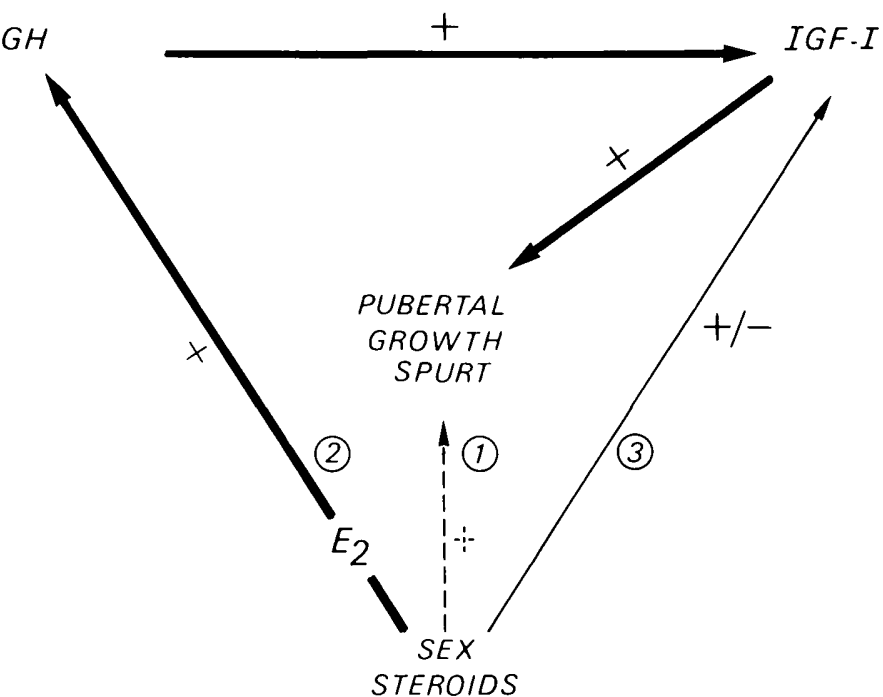

FIG. 3. Schematic representation of the hormonal mechanisms possibly involved in the pubertal growth spurt.

\section{The Auxological Parameters Used to Evaluate Growth at Puberty and to Predict its Importance for Final Height}

\section{A. Pubertal growth}

It is interesting to examine the adequacy of the auxological parameters that we use to evaluate pubertal growth. Peak height velocity is a commonly used index of pubertal growth. It can be optimally calculated by fitting the height velocity curve when a sufficient amount of data have been obtained. In physiological variants of growth, differences in peak height velocity are consistent with differences in total pubertal height gain. This is because physiological increase or reduction in amplitude of peak height velocity is associated with parallel increase or reduction in duration of the growth spurt (91). However, this is no longer true in severely delayed puberty such as in hypopituitarism (134). In these patients, advancement in bone age at onset of puberty results in a prominent reduction in duration of puberty while the amplitude of their growth spurt is less affected. Therefore, they show a $57 \%$ decrease in total pubertal height gain between 11.0 and $15.0 \mathrm{yr}$ at onset of puberty while peak height velocity is only reduced by $22 \%$ at the same time (Fig. 4).

Thus, the evaluation of pubertal growth in pathological situations should be performed using total pubertal height gain rather than peak height velocity or growth rate which are calculated after a follow-up of 1 or $2 \mathrm{yr}$ during puberty. In fact, peak height velocity and growth rate are used because most studies are performed before final height has been attained. While such studies provide some indication of the growth response to sex steroids, total pubertal height gain cannot be extrapolated 


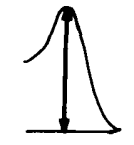

Fig. 4. Peak height velocity (left panel) and total pubertal height gain (right panel) in relation to bone age at onset of puberty in 22 hypopituitary boys studied during spontaneous puberty $(\boldsymbol{\Lambda})$ or testosterone therapy (0). Individual data are shown in the lower panels. The upper panels represent the slopes of the correlations as a percentage of the values seen at $11.0 \mathrm{yr}$ of bone age. The upper part of the figure illustrates schematically the differences in peak height velocity and total pubertal height gain. [Reproduced with permission from J. P. Bourguignon: Acta Pediatr Scand [Suppl] 343, 1988 (134).]

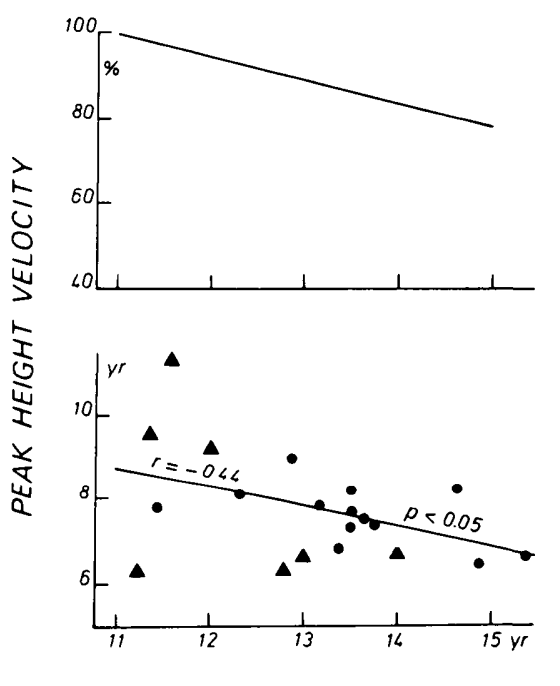

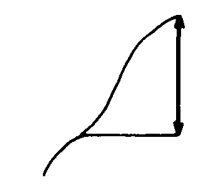
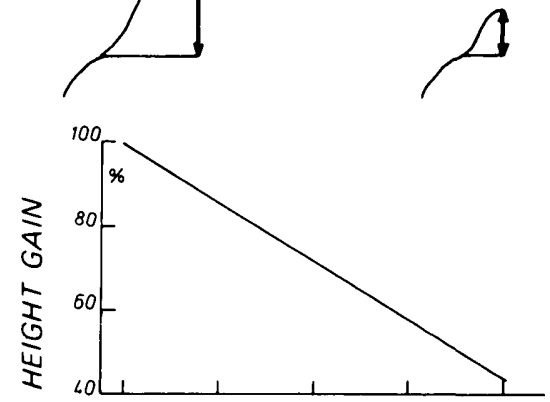

BONE AGE AT ONSET OF PUBERTY from the growth rate seen immediately after onset of puberty.

\section{B. Final height predictions}

Obviously, final height cannot be determined until epiphyseal cartilages have closed. Since it takes such a long time to attain final height, in the clinical setting we attempt to predict the ultimate stature of patients in order to evaluate the likely effects of therapeutic modalities. For instance, in patients with central precocious puberty treated with GnRH agonists, there are no data available on ultimate height so that, to date, only predictions can be used.

Some auxological parameters studied in relation to final height are summarized in Table 2. Adult stature represents the sum of height gains obtained at different periods of life. Puberty is the last important period of life for height gain since postpubertal growth is minimal. At each growth period, including puberty, height gain is the product of two parameters: height velocity and duration of growth. For a given period of growth, height velocity is the height increment ( $\Delta$ height) over $\Delta$ chronological age. During that period, duration of growth is a direct function of chronological age but inversely related to $\Delta$ bone age, which is the rate of bone maturation. Thus, height gain during a given period of life is directly related to $\Delta$ height and inversely related to $\Delta$ bone age. Consequently adult stature is also a direct function of $\Delta$ height and an inverse function of $\Delta$ bone age.

According to the statements above, predictive evaluation of the effects of any endocrine condition or therapy
TABLE 2. Auxological parameters used to evaluate the relative influences of growth rate and age on adult stature

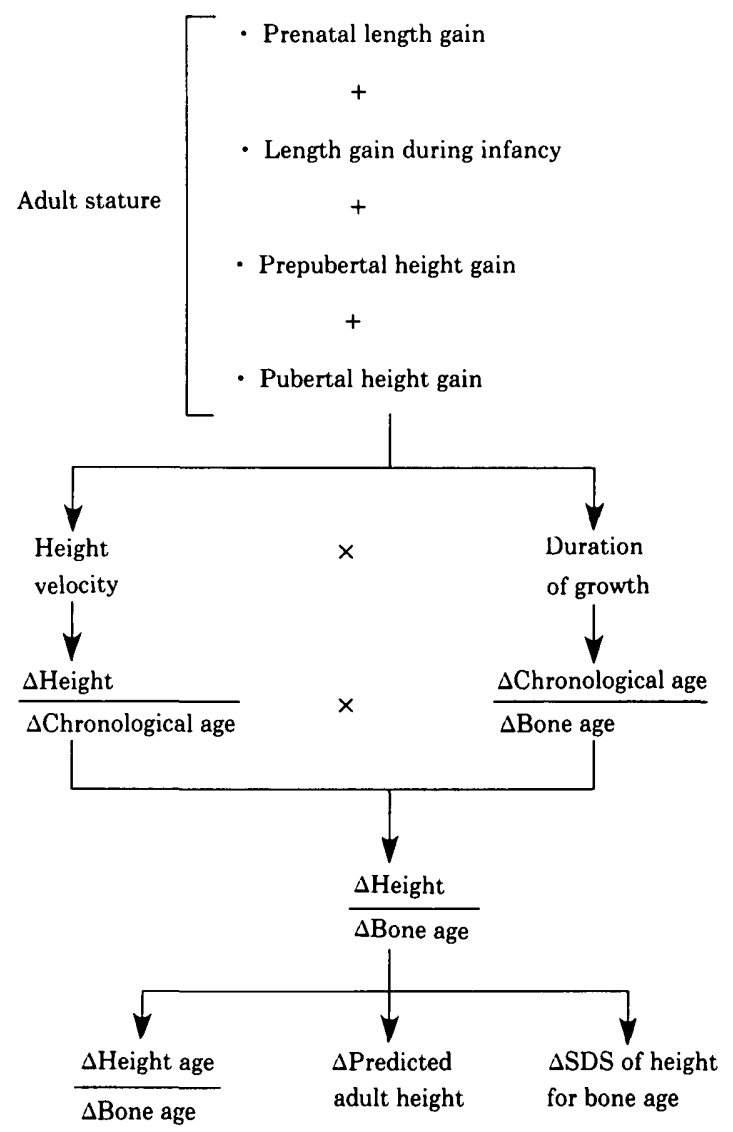


on ultimate height must rely on studies of the rate of linear growth ( $\Delta$ height) vs. the rate of bone maturation ( $\Delta$ bone age). Before adult stature is attained, the three following parameters are commonly used in order to relate growth rate and bone maturation rate (Table 2): the ratio of $\Delta$ height age to $\Delta$ bone age $(\Delta \mathrm{HA} / \Delta \mathrm{BA})$, the $\Delta$ predicted adult height and the $\Delta$ Standard Deviation Score (SDS) of height for bone age. These three parameters are all dependent on the estimation of bone age which includes errors inherent to the reading of the $x$ ray film and the characteristics of the children used as controls. These errors restrict the significance of any method of final height prediction. In addition, the degree of shortness may bias the calculations used to estimate the ratio between $\Delta$ height and $\Delta$ bone age. Such biasing effects can be shown using theoretical growth data (Fig. 5).

In Fig. 5a are illustrated theoretical data of height in relation to bone age in three subjects. These subjects differ only by their height at the beginning of a $1 \mathrm{yr}$ study $(140,155$, and $170 \mathrm{~cm})$ while they show the same height gain of $5 \mathrm{~cm}$ and the same increase in bone age from 14.0 to $15.0 \mathrm{yr}(\triangle \mathrm{BA}=1.0 \mathrm{yr})$ during the study. In Fig. 5b, it is shown how height ages and $\Delta \mathrm{HA}$ are calculated using the heights of the three subjects and the 50th centile curve of height from the standards of Tanner and Davies (18). Since the 50th centile curve is not rectilinear but changes with age, particularly at puberty, the calculation of height age is markedly influenced by the degree of shortness which is different among the three subjects. This is why they show $\Delta \mathrm{HA}$ varying between 0.5 and 1.4 yr while their $\triangle \mathrm{BA}$ is $1.0 \mathrm{yr}$. Thus, calculation of $\triangle \mathrm{HA} /$ $\triangle \mathrm{BA}$ ratio is biased by the degree of short stature which affects $\triangle \mathrm{HA}$. Because of such biasing effect, $\triangle \mathrm{HA} / \Delta \mathrm{BA}$ does not represent a suitable index for relating growth rate and bone maturation rate.

Calculation of predicted adult height provides another means of integrating the rate of growth and the rate of bone maturation. This calculation can be done using tables or equations based on sex, height, and bone age which are the main data used to predict final height. In a previous study by Zachmann et al. (135) comparing different methods of adult height prediction, it was concluded that the method of Bayley-Pinneau (136) using bone ages rated according to Greulich and Pyle (137) provided the most consistent predictions. Final height predictions are less accurate in patients showing marked deviations from the range of physiological variations in height or marked differences between bone age and chronological age. In addition, height predictions may be biased by the degree of shortness, as shown in Fig. 5c. Using the equations of Tanner et al. (138), we have calculated predicted adult heights in the three subjects studied for $1 \mathrm{yr}$. While those subjects had identical bone ages, height gains, and $\triangle \mathrm{BA}$, they had different changes in predicted adult heights. The tallest one would gain 0.8 $\mathrm{cm}$ while the shortest would lose $1.9 \mathrm{~cm}$. This represents a relatively minor error after a $1 \mathrm{yr}$ study. However, the

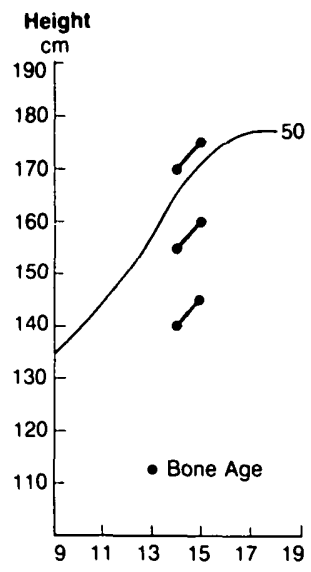

b.

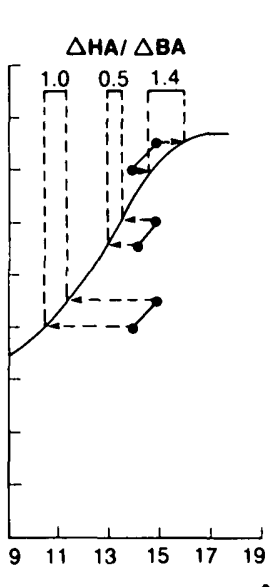

c.

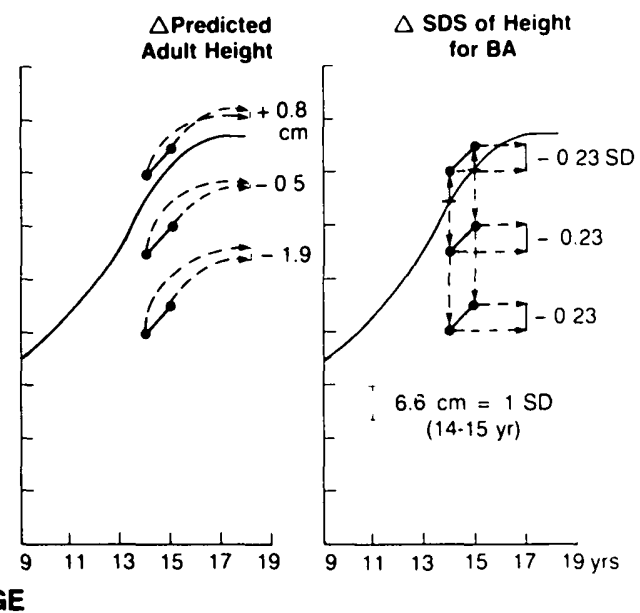

FIG. 5. Influence of the degree of short stature on three methods used to evaluate growth rate in relation to bone maturation rate. a) Height in relation to bone age is shown in three subjects with identical bone ages, growth rates, and bone maturation rates but different degree of short stature. Curve 50 represents the 50 th centile of height for average maturers according to Tanner and Davies (18). b) The ratios $\Delta$ height age/ $\Delta$ bone age have been calculated for the three subjects. The broken lines indicate how the height ages are calculated. $\Delta \mathrm{Bone}$ age is $1 \mathrm{yr}$ in the three subjects. c) Predicted adult heights [TW mark II equations, (138)] have been calculated at 14.0 and 15.0 yr of bone age for each subject. The numbers indicate the differences between the two predictions calculated for each of the three subjects. d) SDS of height for bone age have been calculated at 14.0 and $15.0 \mathrm{yr}$ of bone age in the three subjects, with reference to height for bone age at the 50th centile as shown by the broken lines. The numbers indicate the differences in SDS of height for BA between 14.0 and $15.0 \mathrm{yr}$ for each of the three subjects. 
biasing effect of the degree of short stature on the calculation of predicted adult height may increase with the length of the study period.

The growth rate can also be related to the rate of bone maturation by calculating the standard deviation score (SDS or Z score) of height for bone age. This is the difference between a patient's height $(x)$ and mean normal height for the same bone age $(\overline{\mathrm{x}})$, divided by the SD of height for that bone age. Thus, SDS $=(x-\bar{x}) /$ SD. Using this calculation, it is shown in Fig. $5 \mathrm{~d}$ that the same $\Delta$ SDS of height for BA $(-0.23 \mathrm{SD})$ is found in the three subjects studied with different degree of short stature. This indicates that $\triangle \mathrm{SDS}$ of height for BA is not biased by the degree of short stature. However, SDS of height for bone age still involves errors inherent to bone age estimation. In addition, the standard deviations of height for chronological age are used improperly for relating height to bone age since there is no available data base of height for bone age.

Thus, when pubertal growth is studied, the important parameter is total pubertal height gain which is the product of mean height velocity and duration of pubertal growth. When we predict how adult stature can be affected by therapies inducing or delaying puberty, height gain and $\triangle \mathrm{BA}$ during therapy are the two major factors. In order to relate these two factors, methods using height age are not appropriate. The calculation of adult height predictions or SDS of height for bone age should be considered carefully. Further recommendations should rely on retrospective studies of different methods for adult height prediction in specific groups of subjects or patients having attained adult stature. It is likely that the methodological errors would be minimized using specific prediction methods for each type of growth disorder.

\section{Role of Sex Steroid Dosage}

Factors such as age at onset of sex steroid action and dosage of sex steroids may determine differences in the rates of growth and bone maturation during pubertal growth. Those two key factors are particularly important in the therapeutic management of patients with disorders of puberty. In the following sections, the role of sex steroid dosage and age at onset of puberty on pubertal growth, bone maturation rate, and final height will be examined in both sexes.

\section{A. Role of estrogens}

Effects of estrogen dosage on pubertal growth. In hypopituitary girls, very limited studies have been published on growth during estrogen therapy $(87,139,140)$. The major data bearing on the importance of estrogen dosage for growth response have been obtained in patients with gonadal dysgenesis (vide infra)

In 1974, Rosenfield and Fang (119) reported on the growth response to low-dose estrogen in subjects with gonadal dysgenesis. In contrast, high doses (equivalent to more than $1 \mu \mathrm{g} / \mathrm{kg}$. day of ethinyl-estradiol), had been shown not to affect the growth rate (141). In a shortterm study using different estrogen doses, Ross et al. (120) observed a 2 -fold increase in the growth rate of the ulna by ethinyl-estradiol $0.1 \mu \mathrm{g} / \mathrm{kg} \cdot$ day. Higher dosages of 0.4 and $0.8 \mu \mathrm{g} / \mathrm{kg}$. day were not effective on bone length, indicating the biphasic nature of estrogen effects upon growth. Although this study only considered the growth of the limbs, growth of the trunk is equally important to the pubertal spurt. More recently, in a double-blind, placebo-controlled study using $0.1 \mu \mathrm{g} / \mathrm{kg}$. day ethinyl-estradiol for 6 months, the same group has shown a $70 \%$-increase in height velocity induced by estrogens (123).

In Fig. 6, the results from 8 available studies on estrogen effects in patients with gonadal dysgenesis are compiled $(119,121,123,124,142-145)$. The data are plotted in relation to bone age at onset of estrogen therapy, which is variable over a range of $6 \mathrm{yr}$ between $8.1 \mathrm{yr}$ (145) and 13.8 yr (143). In all these studies, bone ages were rated according to Greulich and Pyle (137) except for patients starting treatment at $13.0 \mathrm{yr}$ of bone age in whom calculations were made according to the method of Tanner et al. (138). In order to include the patients studied by Ross et al. (123), mean bone age was arbitrarily considered to be delayed 1.5 yr below their mean chronological age, based on the findings of Martinez et al. (124). While weight was not stated by the authors, body weight-related doses of estrogen were calculated for a 40 $\mathrm{kg}$ patient $(119,141-143,145)$. The following drug equivalents were used in this compilation: $10 \mu \mathrm{g} /$ day ethinylestradiol $(\mathrm{EE})=1 \mathrm{mg} /$ day $17 \beta$-estradiol (given orally) $=$ $2 \mathrm{mg} /$ month of long-acting estradiol ester (given im) $=$ $0.3 \mathrm{mg} /$ day conjugated estrogens (given orally).

The interpretation of the effects of estrogen dosage upon growth in patients with gonadal dysgenesis is difficult since available information involves differences in estrogen dose and differences in age at onset of administration. When these studies are reviewed (Fig. 6), the dose of estrogen used does not seem to play a major role in determining the immediate growth response. This is quite clear in the 4 groups of patients beginning treatment between 11.1 and $12.1 \mathrm{yr}$ of bone age $(121,142$, $143,145)$. They exhibit similar growth rates despite the use of very different estrogen dosages. However, it is still possible that estrogen dosage will influence the total pubertal height gain since the growth rates observed during the first year of estrogen therapy may not parallel the total pubertal height gain. 


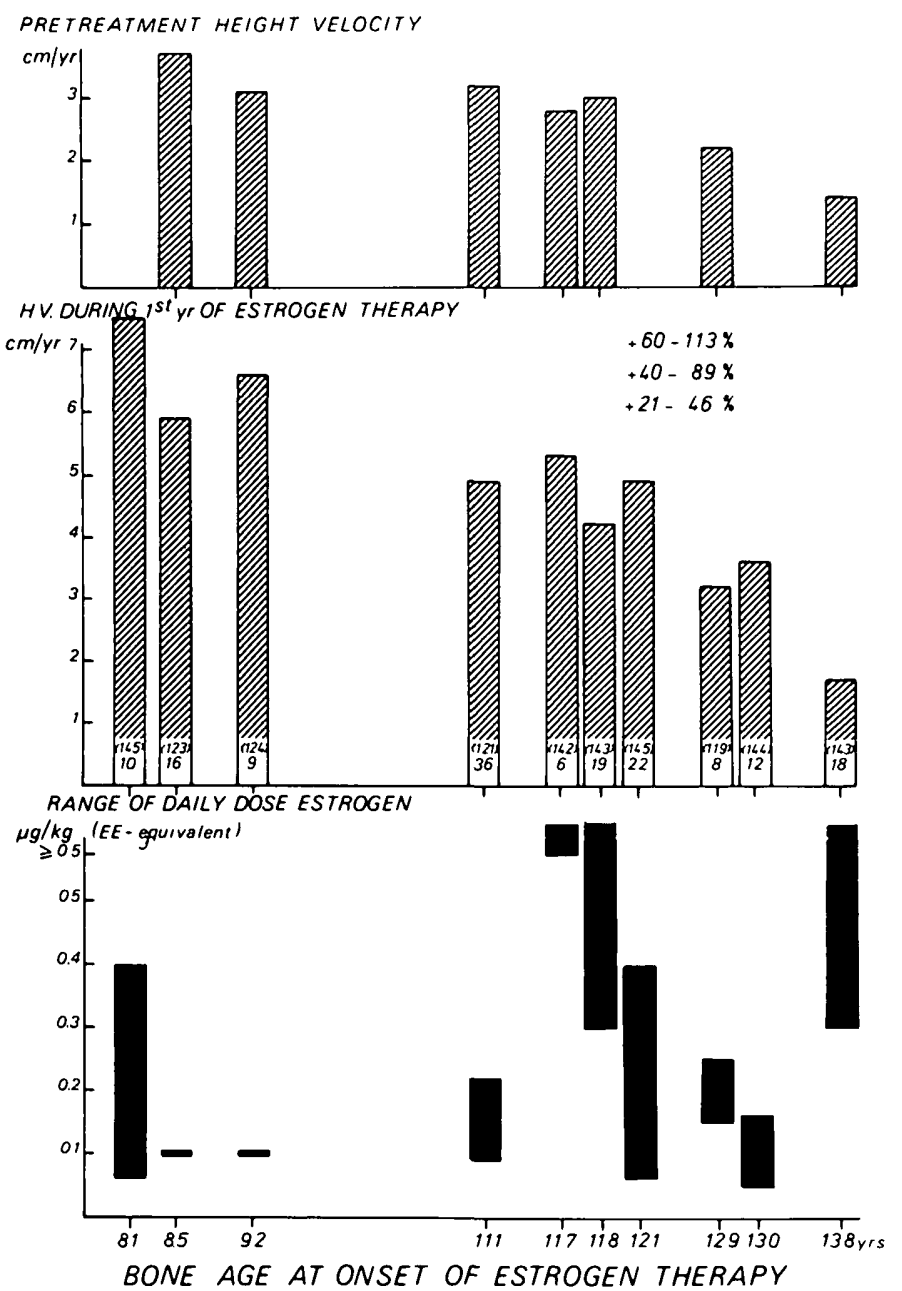

FIG. 6. In patients with gonadal dysgenesis, mean height velocity (H.V.) before therapy (upper panel), mean height velocity during the first year of estrogen therapy (middle panel), and the ranges of daily estrogen dosage (lower panel) are plotted in relation to mean bone age at onset of treatment. (Data compiled from Refs. 119, 121, 123, 124, 142-145). In the bars, the numbers of patients studied are indicated, and the original references for the data used are given between parentheses.

Effects of estrogen dosage on the rate of bone maturation. In patients with gonadal dysgenesis and, by inference, in normal girls, the dose of estrogen may be critical for the rate of bone maturation. In several studies of Turner's patients compiled in Fig. 7, left panel (119, 123, 124, 142, 145), $\triangle \mathrm{BA} / \triangle \mathrm{CA}$ has been estimated according to Greulich and Pyle (137). In order to include the data from Ross et al. (123) in this compilation, bone age at onset of estrogen therapy was assumed to be $8.5 \mathrm{yr}(1.5 \mathrm{yr}$ below mean chronological age). As shown in Fig. 7, in patients who began estrogen therapy before a mean bone age of $10 \mathrm{yr}$, Kastrup et al. (145) observed a mean $\triangle \mathrm{BA} /$ $\triangle \mathrm{CA}$ of 2.92 using a daily dose of ethinyl-estradiol ranging between 0.1 and $0.4 \mu \mathrm{g} / \mathrm{kg}$. In contrast, using a lower dose of $0.1 \mu \mathrm{g} / \mathrm{kg}$, Ross et al. (123) and Martinez et al. (124) found $\triangle \mathrm{BA} / \triangle \mathrm{CA}$ to be 0.92 and 1.65 , respectively.

Effects of estrogen dosage on final height. To date, we lack information about final height in relation to the dosage of estrogens used as replacement therapy. In tall girls, treatment with high doses of estrogens has been shown to induce an acceleration in bone maturation accounting for the decrease in ultimate height $(66,129$, 146-148). This indicates that the biphasic effect of estrogens on the growth rate differs from the consistent acceleration in bone maturation rate seen with the administration of high doses $(\geq 0.1 \mathrm{mg} /$ day) of ethinylestradiol (149).

\section{B. Role of androgens}

Effects of androgen dosage on pubertal growth. In hypopituitary boys, pubertal growth has been studied during therapy with testosterone enanthate at different dosages ranging between 100 and $250 \mathrm{mg} / \mathrm{month}(57,85-87,89$, 90). In these studies (Fig. 8), treatment was started at similar bone ages (12.8-14.0 yr). In addition, hGH therapy was given at similar doses varying between 12 and $19.5 \mathrm{IU} /$ week. While the different dosages of testosterone resulted in minimal differences in peak height velocity, between 6.3 and $8.0 \mathrm{~cm} / \mathrm{yr}$, the total pubertal height gain was 2 -fold higher using testosterone $100 \mathrm{mg} /$ month compared to using $250 \mathrm{mg} /$ month (Fig. 8). This illustrates not only the importance of testosterone dosage but also the discrepancy between peak height velocity and total pubertal height gain which has been described above.

A monthly injection of $100 \mathrm{mg}$ testosterone enanthate, is, in fact, too high for beginning hormone replacement therapy (86). As shown in Fig. 9, GH-treated hypopituitary patients who were given testosterone enanthate 100 $\mathrm{mg} / \mathrm{month}$ revealed an earlier occurrence of stages 4 and 5 of genital development and an earlier achievement of peak height velocity than hypopituitary boys developing spontaneous puberty. This is consistent with plasma testosterone levels which were higher during therapy than during the first year of spontaneous puberty. It is to be noted that the testosterone levels measured the first week after the injection would have been even higher.

Effects of androgen dosage on the rate of bone maturation. During normal puberty, sex steroids may accelerate the bone maturation rate. In boys Buckler (150) reported an acceleration of bone maturation rate $(\triangle \mathrm{BA} / \Delta \mathrm{CA}=1.73)$ concomitant with the peak height velocity. In hypopituitary boys, dosage is also important for the effect of testosterone on bone maturation. As shown in Fig. 8 (lower panel), $\triangle \mathrm{BA} / \triangle \mathrm{CA}$ is less in patients treated with testosterone enanthate 100 or $150 \mathrm{mg} /$ month $(57,86)$ than in those receiving 200 or $250 \mathrm{mg} /$ month $(89,90)$. 

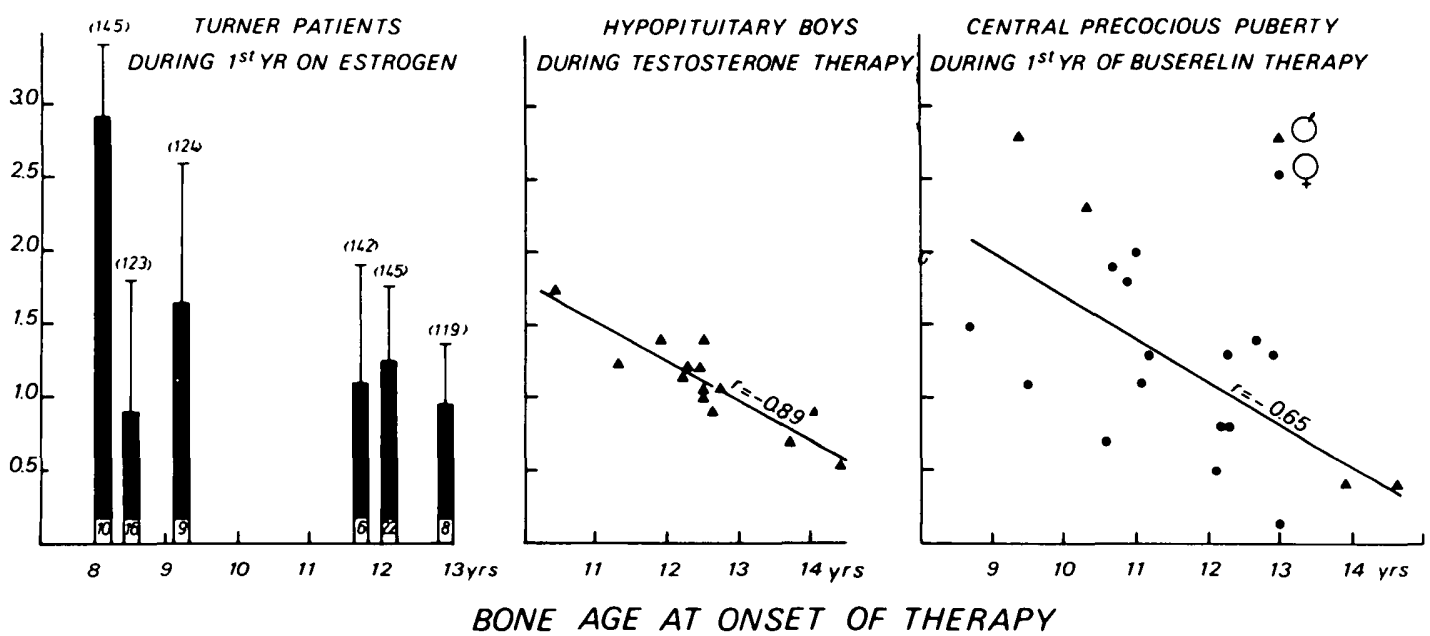

FIG. 7. The velocity in bone maturation $(\triangle \mathrm{BA} / \Delta \mathrm{CA})$ during treatment for induction or inhibition of sexual maturation is plotted in relation to pretreatment bone age in different conditions: Turner patients during the first year of estrogen therapy (mean \pm 1 SD calculated from Refs. 119, $123,124,142$, and 145), (left panel); hGH-treated hypopituitary boys during supplementation with testosterone enanthate $100 \mathrm{mg} / \mathrm{month}$ for a mean period of $2.7 \mathrm{yr}$ [Reproduced with permission from J. P. Bourguignon et al:: J Clin Endocrinol Metab 63:376, 1986 (86)], (middle panel); and patients with central precocious puberty during the first year of treatment with buserelin, a GnRH agonist [Reproduced with permission from J. P. Bourguignon et al.: Acta Endocrinol (Copenh) 116:519, 1987 (155)], right panel. The number of Turner patients (left panel) is indicated in the bars, and the references are cited in parentheses over the error limits.

Effects of androgen dosage on final height. In excessively tall boys, long acting esters of testosterone given at a high dosage of $500 \mathrm{mg}$ twice a month result in a reduction of final height $v s$. adult height predicted before therapy (151).

In hypopituitary boys who have been treated with replacement doses of long acting testosterone usually varying between 100 and $250 \mathrm{mg} / \mathrm{month}$, it is difficult to draw conclusions since several other important factors such as age at onset of GH therapy and height at onset of puberty may interact. In addition, the amount of testosterone given to initiate therapy and the duration of low dose treatment may play some role. Nonetheless, data on adult stature obtained in different studies (85$87,89,90$ ) are in a relatively narrow range between -1.4 and $-2.0 \mathrm{SD}$, suggesting that, in the range of doses used (100-250 mg/month), there is no major effect of androgen dosage on final height. Lower doses (25 or $50 \mathrm{mg} /$ month) maintained for the first year of treatment require further study.

\section{Role of Age at Onset of Puberty}

Bone age represents an index of maturation which is more closely related to growth than chronological age. This is particularly obvious for patients who deviate significantly from the normal tempo of growth and puberty. In some instances, data on bone age may not be available. Therefore, puberty and final height have also been studied in relation to chronological age in male subjects.

\section{A. Girls}

Effects of age at onset of female puberty on pubertal growth. In hypopituitary girls, there is a possible role for bone age in determining growth response to sex steroids. In $\mathrm{GH}$-treated girls starting estrogen therapy at mean bone ages of 12.3 (139) and $13.2 \mathrm{yr}(87)$, total pubertal height gain is minimal (2 and $5.2 \mathrm{~cm}$, respectively). Such a low response of growth to estrogens has been confirmed by Rolland et al. (140). In contrast, during spontaneous puberty in $\mathrm{GH}$-treated girls, total pubertal height gains of 22 (87) and $23 \mathrm{~cm}$ (85) have been reported. These differences in pubertal growth may relate to the bone age at onset of spontaneous breast development (10.1 and $10.4 \mathrm{yr}$, respectively) compared to the age at onset of estrogen therapy (12.3-13.2 yr).

Interesting information on the role of age on growth response to estrogens has also been obtained in patients with variants of gonadal dysgenesis. These individuals do not represent the most appropriate model for sex steroid effects on growth since there is impaired growth during intrauterine life and during the prepubertal period as well $(152,153)$. In addition, relatively high dosages of GH are required to improve growth in Turner patients $(35,154)$.

As shown in the upper panel of Fig. 6, in accordance 

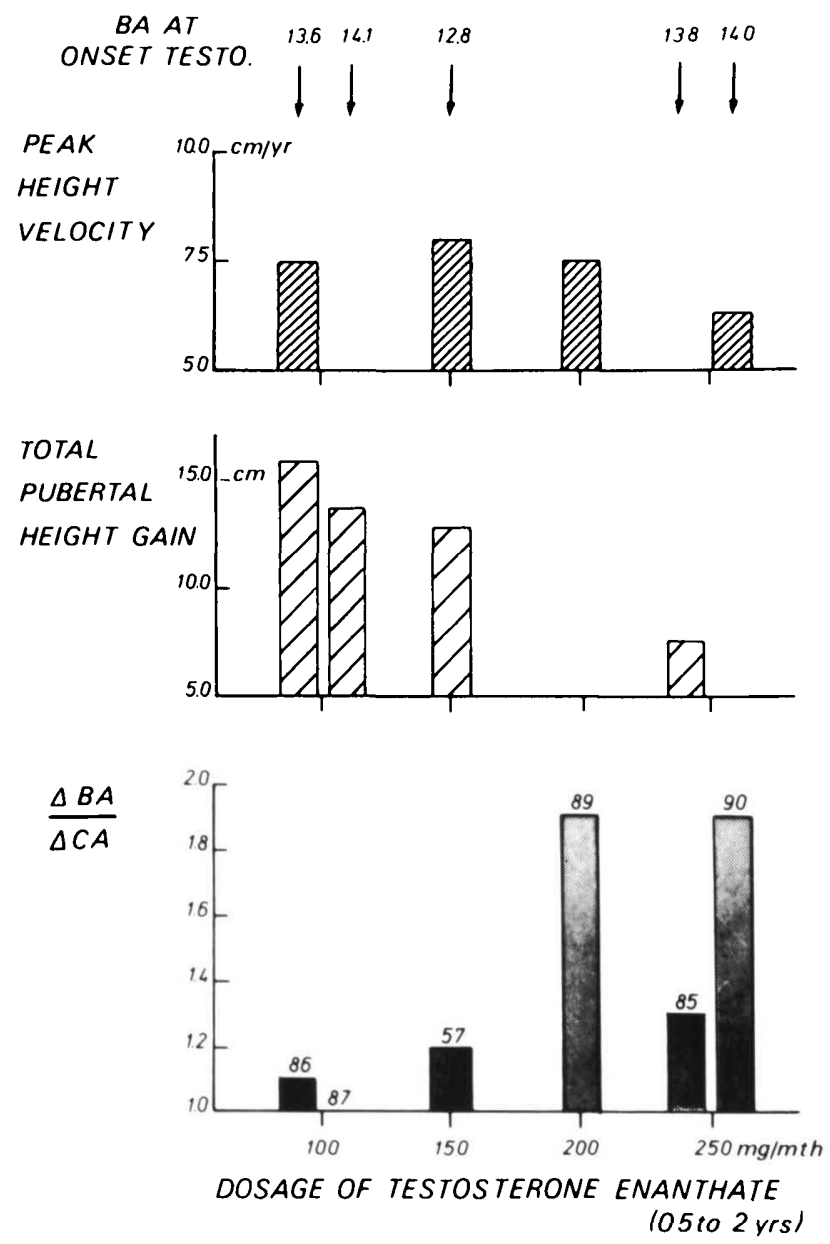

FiG. 8. Effects of a 0.5 to 2-yr course of testosterone therapy at different doses on peak height velocity, total pubertal height gain, and the rate of bone maturation $(\triangle \mathrm{BA} / \Delta \mathrm{CA})$ in hypopituitary boys. The numbers in parentheses indicate the references. When available, bone age at onset of testosterone therapy is indicated at the top of the figure.

with observations in untreated patients $(152,153)$, there is a progressive decline of pretreatment height velocity with age. Growth response during the first year of estrogen therapy (Fig. 6, middle panel) follows a similar agerelated reduction from 7.5 to $1.7 \mathrm{~cm} / \mathrm{yr}$. These findings not only reflect the impact of pretreatment height velocity but also a decrease in responsiveness to estrogens with age. In fact, the increase in height velocity over pretreatment level was $60-113 \%$ before $10 \mathrm{yr}$ of bone age, $40-89 \%$ between 11 and $12 \mathrm{yr}$, and $21-46 \%$ between 13 and $14 \mathrm{yr}$.

Effects of age at onset of female puberty on the rate of bone maturation during puberty. As shown in Fig. 7 (left panel), during estrogen administration to patients with gonadal dysgenesis, $\triangle \mathrm{BA} / \triangle \mathrm{CA}$ tends to decrease in relation to bone age at onset of therapy. Such a negative relationship between $\triangle \mathrm{BA} / \triangle \mathrm{CA}$ calculated according to Tanner et al. (138) and pretreatment bone age exists in
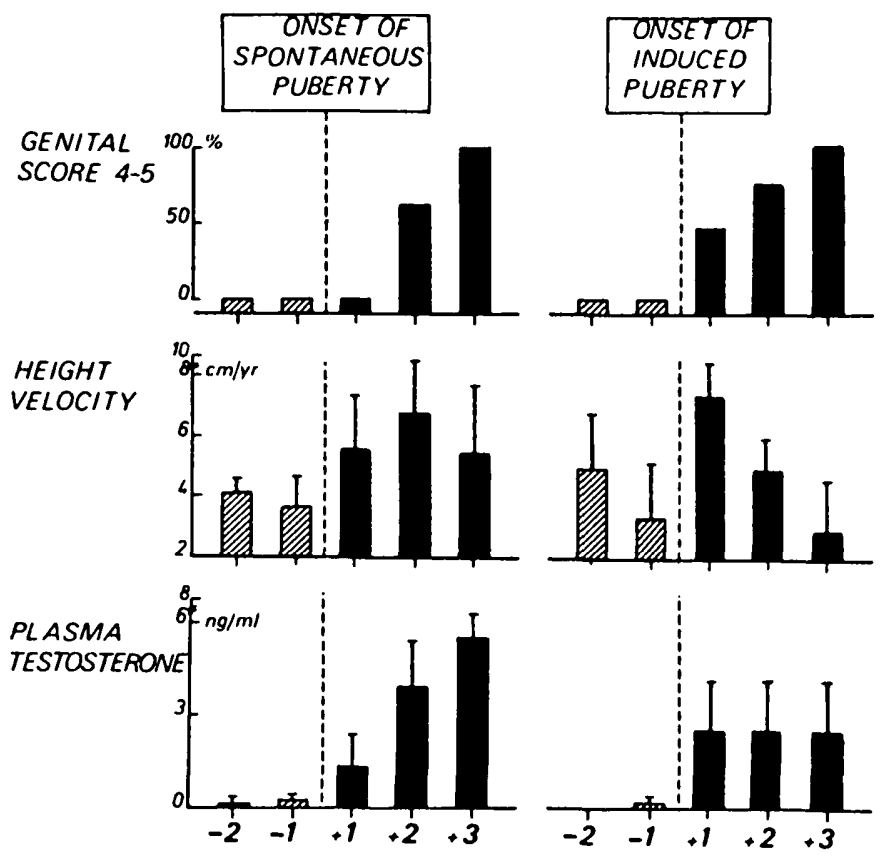

Time (yrs) before $1-1$ \& after $1+10$ nset of puberty

FIG. 9. Pubertal development in GH-treated boys with normal gonadotropin secretion (left panels, $\mathrm{n}=8$ ) or with gonadotropin deficiency (right panels, $\mathrm{n}=14$ ). Mean ( $\pm 1 \mathrm{SD})$ score of genital development (stages 4 and 5 according to Tanner), mean height velocity, and mean plasma testosterone levels are shown in relation to time before and during spontaneous puberty or testosterone therapy (testosterone enanthate $100 \mathrm{mg} / \mathrm{month} \mathrm{im}$ ). In testosterone-treated patients, blood for testosterone measurement was obtained about 2 weeks after the last injection of testosterone enanthate $100 \mathrm{mg}$. [Adapted with permission from J. P. Bourguignon et al:: J Clin Endocrinol Metab 63:376, 1986 (86).]

patients with central precocious puberty (155) during treatment with buserelin, a superagonist of GnRH (Fig. 7 , right panel). For patients with precocious puberty, a similar correlation has been found by Boepple et al. (156) in girls treated with the [D-Trp ${ }^{6}-\operatorname{Pro}^{9}-N$-ethylamide]GnRH analog.

Effects of age at onset of female puberty on final height. While the reduction of adult stature in girls with early exposure to estrogens is well established $(1,2)$, the effects of late onset of estrogen therapy on final height are unknown. This is partly explained by the low incidence of conditions such as hypogonadotropic hypogonadism or panhypopituitarism in females as compared to males. This question deserves further study, particularly because the growth response to estrogens in girls seems to be more age-dependent than the response to androgens in boys (vide infra).

\section{B. Boys}

Effects of age at onset of male puberty on pubertal growth. In normal children, there is an age-related decrease of 
pubertal height gain as indicated by the early observations of Boas (157). Several authors have confirmed this relationship using peak height velocity $(91,92)$ or pubertal height gain (158) as the index of pubertal growth.

In hypopituitary boys, the role of bone age on growth response to testosterone therapy has been known from early data obtained using high doses of androgens (testosterone enanthate $\geq 300 \mathrm{mg} / \mathrm{m}^{2} \cdot$ month) before hGH treatment was available. After initiating testosterone administration at a mean bone age of $13.5 \mathrm{yr}$, AynsleyGreen et al. (57) obtained a maximal growth rate of 5.5 $\mathrm{cm} / \mathrm{yr}$ during a $1.9 \mathrm{yr}$ period of treatment. This observation is similar to the $5.2 \mathrm{~cm} / \mathrm{yr}$ reported by Zachmann and Prader (159) under the same conditions. In contrast, when testosterone was started at $8.5 \mathrm{yr}$ of mean bone age, Blizzard et al. (8) obtained a more pronounced increase in height velocity, up to $8.5 \mathrm{~cm} / \mathrm{yr}$ (recalculated from their data).

As shown in Fig. 10, the parameters of pubertal growth exhibit a similar pattern of variation in relation to bone age in hypopituitary boys and in relation to chronological age in groups of subjects or patients beginning puberty at different ages between infancy and early 20s (134). The total pubertal height gain is negatively related to age at onset of puberty. It can be seen in Fig. 10 that the age-related decrease in total pubertal height gain is explained by a reduction in duration of pubertal growth. In contrast, there are only minor differences in mean pubertal growth rate which has been calculated as the total height gain divided by the duration of puberty.

Effects of age at onset of male puberty on the rate of bone maturation during puberty. During testosterone therapy in GH-treated hypopituitary boys (Fig. 7, middle panel), as well as during spontaneous puberty in boys with isolated GH deficiency (86), the rate of skeletal maturation decreases with age at onset of puberty. As a matter of fact, when referred to an average normal $\triangle B A / \triangle C A$ of 1 , patients starting puberty at an early bone age have a rapid rate of bone maturation during puberty while those entering puberty at a late bone age have a slow rate of bone maturation during puberty. The question arises whether or not those age-related differences in bone maturation rate play some role in the different
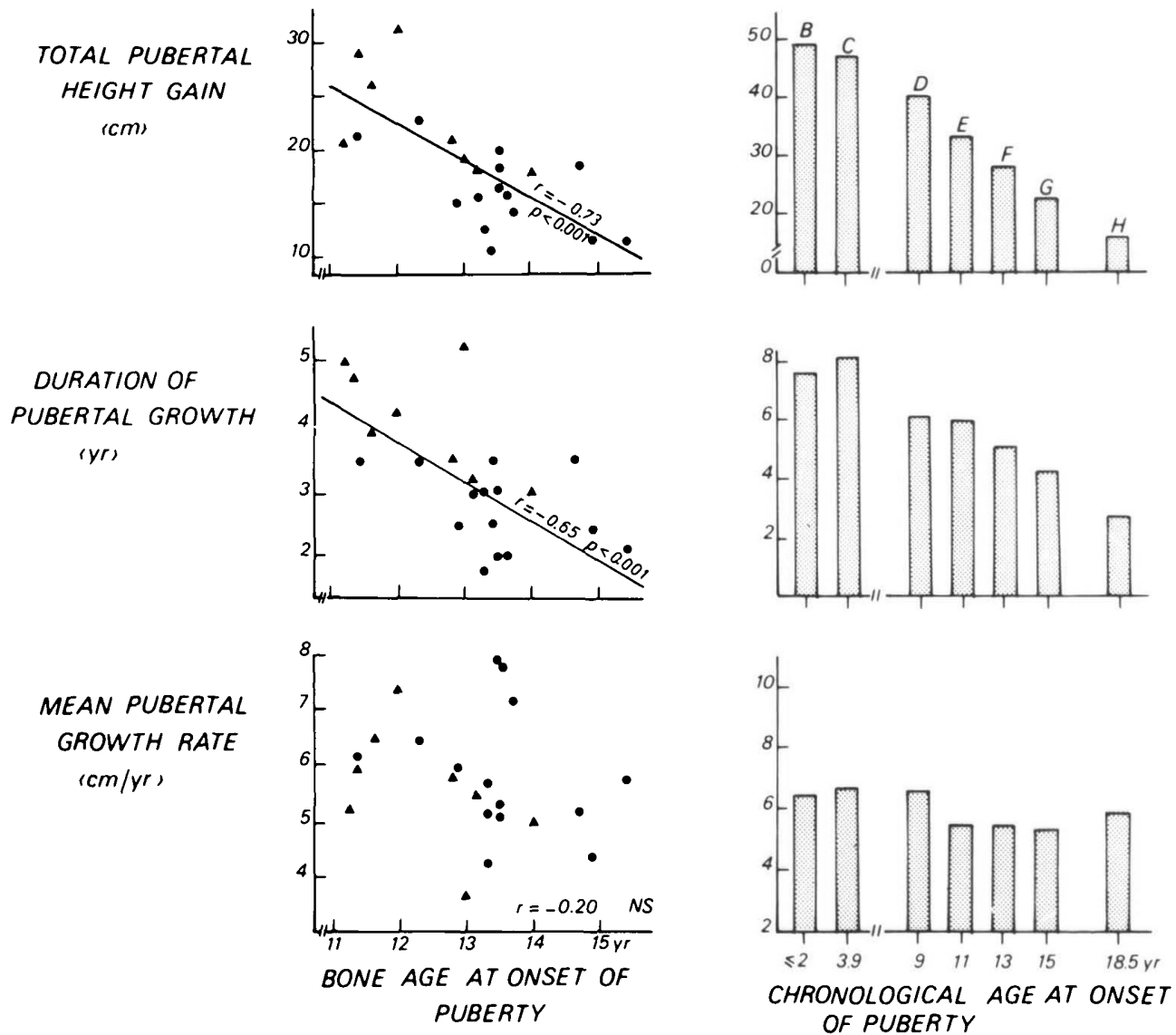

Fig. 10. Total pubertal height gain, duration of pubertal growth, and mean pubertal growth rate in relation to age at onset of puberty. Left panels, Individual data of hypopituitary boys ( $\boldsymbol{\Lambda}$, spontaneous puberty, $\boldsymbol{\bullet}$, testosterone-induced puberty) in relation to bone age. Right panels, data compiled from the literature and studied in relation to chronological age; groups B and C: boys with idiopathic precocious puberty (1, 2); groups D, E and F: normal boys maturing at early, average, and late tempos (18); groups G and H: GH-treated hypopituitary boys with spontaneous and testosterone-induced puberty (86). [Reproduced with permission from J. P. Bourguignon: Acta Paediatr Scand [Suppl] 343, 1988 (134).] 
patterns of pubertal growth determined by age at onset of puberty. These different patterns relate to duration of pubertal growth which decreases with age at onset of puberty (Fig. 10). An increased rate of bone maturation would account for a reduced duration of pubertal growth and vice versa. In fact, the opposite phenomenon is observed, a reduced rate of bone maturation being seen in patients with reduced duration of puberty. This indicates that variations in the rate of bone maturation with age at onset of puberty do not contribute to the differences in duration of pubertal growth. Rather, variations in the rate of bone maturation appear as a compensatory mechanism which may counteract, to some extent, the differences in duration of puberty determined by the timing of its onset.

Effects of age at onset of male puberty on final height. As shown in Fig. 11, in boys with idiopathic precocious puberty beginning at a mean age of less than $2.0 \mathrm{yr}(\mathrm{n}=$ 5 , group B) and $3.9 \mathrm{yr}(\mathrm{n}=4$, group $\mathrm{C})$, there is a $30.1-$ and $20.6-\mathrm{cm}$ reduction of final height $(1,2)$ when compared to $176.8 \mathrm{~cm}$ which is the 50 th centile of height for normal adult males (18). The observations in central precocious puberty are consistent with the mean adult height reduction of $23.0 \mathrm{~cm}$ seen in nine boys with untreated congenital adrenal hyperplasia $(1,3,5,6$, group A). Also, in girls with central precocious puberty, a direct relationship exists between adult height and age at onset of puberty (2). In boys with severe sexual precocity, the reduction in prepubertal height gain, as indicated by height at onset of puberty (Fig. 11), is much more important than the increase in pubertal height gain and accounts for their reduced adult stature (134).

While severe sexual precocity results in impairment of adult stature $(1,2)$, similar adult heights are found in longitudinal studies (18) of normal boys maturing at early, normal, or late tempos (Fig. 11: groups D, E, and F). This is in accordance with several reports on normal adult stature in boys with constitutional delay of puberty, not treated with androgens. The differences in adult
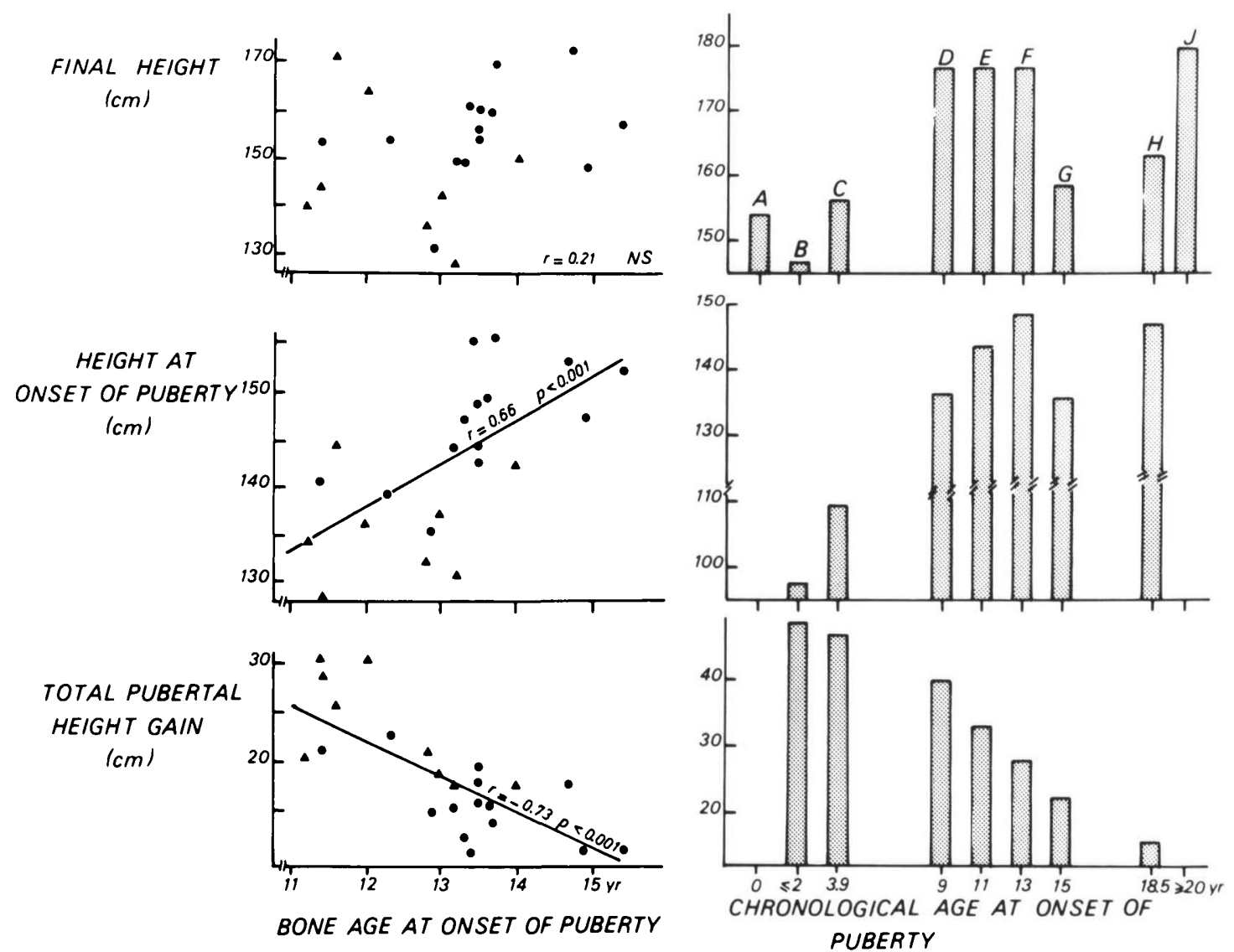

Fig. 11. Final height, height at onset of puberty, and total pubertal height gain in relation to age at onset of puberty. Left panels, Individual data of hypopituitary boys ( $\boldsymbol{\Lambda}$, spontaneous puberty, $\boldsymbol{\bullet}$, testosterone-induced puberty) in relation to bone age [Adapted with permission from J. P. Bourguignon et al.: $J$ Clin Endocrinol Metab 63:376, 1986 (86).] Right panels, Data compiled from the literature and studied in relation to chronological age; group A: boys with untreated congenital adrenal hyperplasia $(1,3,5,6)$; groups B and C: boys with idiopathic precocious puberty $(1,2)$; groups D, E, and F: normal boys maturing at early, average and late tempos (18); groups G and H: GH-treated hypopituitary boys with spontaneous and testosterone-induced puberty (86); group J: men with hypogonadotrophic hypogonadism (58, 59). [Reproduced with permission from J. P. Bourguignon: Acta Paediatr Scand [Suppl] 343, 1988 (134).] 
height reported by some authors $(160,161)$ may be explained by differences in parent's height $(162,163)$.

In GH-deficient patients with idiopathic hypopituitarism, late onset of replacement hGH therapy accounts for the possible loss of some growth potential as indicated by short adult stature. However, GH-deficient patients with spontaneous puberty (Fig. 11: group G) can be compared with those treated using testosterone (group $\mathrm{H}$ ). As shown in Fig. 11, while there is a difference of 3.5 $\mathrm{yr}$ of chronological age at onset of puberty between these two groups of patients, the difference in mean final height between both groups is only $4.0 \mathrm{~cm}$ (86). Analysis of individual data obtained in hypopituitary boys in relation to bone age (Fig. 11, left panels) indicates the existence of opposite variations in prepubertal and pubertal height gains. Since these variations are of similar importance, they counterbalance one another, resulting in the absence of obvious differences in final height (86). Our observations are consistent with those of Burns et al. (85) and Ranke and Butenandt (87), who found mean adult height to be, respectively, 2.0 and $2.6 \mathrm{~cm}$ greater in testosterone-treated patients than in those undergoing spontaneous puberty.

The purest model of severely delayed puberty is provided by patients with isolated gonadotropin deficiency not treated before fusion of growth cartilages (group J, Fig. 11). Recently, Van Dop et al. (59) reported that height attained by these patients was at, or very close to, the 50th centile of height for adult males (59). In another study, mean final height of Kallmann's patients (58), not treated before age 20 , was only $4.2 \mathrm{~cm}$ above the 50 th centile.

C. Summary: importance of sex steroid dosage and age at onset of puberty for subsequent growth and final height

In Table 3 are summarized the observations discussed in sections IV and V. Sex steroid dosage has some, but not a major effect, on the immediate growth rate. However, the dosage affects directly the rate of bone maturation and may, therefore, reduce the total pubertal height gain. The impact of sex steroid dosage on duration of puberty and adult stature is unknown.

In both sexes, sexual precocity increases the immediate growth rate and the total pubertal height gain, as compared to average maturers. There is an increased duration of puberty which is compensated for by an increased rate of bone maturation. The increase in total pubertal height gain is not sufficient to counterbalance the markedly reduced period of prepubertal growth. Thus, final height is reduced.

In both sexes, delayed puberty reduces the immediate growth rate and the total pubertal height gain, as compared to average maturers. Also, there is, in boys at least, a reduced duration of puberty which is compensated for by a reduced rate of bone maturation. The reduction in total pubertal height gain counterbalances the increase in prepubertal height gain. Thus, final height is not affected.

These conclusions are drawn on the basis of preliminary observations in pathological conditions and the data presented warrant further studies. However, some evaluation of our therapeutic attitudes can be based on the data reviewed above.

\section{Therapeutic Implications}

In accordance with Prader $(164,165)$, we may conclude that sex steroids exhibit remarkable interactions with the dynamics of growth and less striking effects on final height. This observation has several clinical implications for the management of patients with short stature and disorders of puberty.

A. In patients with primary or secondary hypogonadism there is no reason for delaying the onset of sex steroid therapy or any treatment modality for inducing sexual maturation. Available information does not indicate significant growth benefit from a late onset of puberty. The psychological correlates of delayed puberty (166) encourage the practitioner to begin those treatments at an age appropriate for the social or school context. In panhypopituitary patients, a delayed onset of

TABLE 3. Effects of sex steroid dosage and age at onset of puberty on subsequent growth, bone maturation, and final height

\begin{tabular}{|c|c|c|c|c|c|}
\hline & $\begin{array}{l}\text { Immediate } \\
\text { growth rate }\end{array}$ & $\begin{array}{c}\text { Total } \\
\text { pubertal } \\
\text { height gain }\end{array}$ & $\begin{array}{c}\text { Bone } \\
\text { maturation } \\
\text { rate }\end{array}$ & $\begin{array}{c}\text { Duration } \\
\text { of } \\
\text { puberty }\end{array}$ & $\begin{array}{l}\text { Final } \\
\text { height }\end{array}$ \\
\hline Estrogen dosage (१) & $\begin{array}{l}\nearrow \searrow \\
\text { Biphasic }\end{array}$ & $?$ & $\nearrow$ & $?$ & $?$ \\
\hline Androgen dosage ( $\left({ }^{\star}\right)$ & Minor & $\searrow$ & $\nearrow$ & $?$ & $?$ \\
\hline Female sexual precocity & $\nearrow$ & $\nearrow$ & $\pi$ & $\nearrow$ & $\searrow$ \\
\hline Male sexual precocity & $\nearrow$ & $\nearrow$ & $\nearrow$ & $\nearrow$ & $\searrow$ \\
\hline Delayed female puberty & $\searrow$ & $\searrow$ & $?$ & $?$ & $?$ \\
\hline Delayed male puberty & $\searrow$ & $\searrow$ & $\searrow$ & $\searrow$ & $=$ \\
\hline
\end{tabular}


pubertal induction will prolong the total period of $\mathrm{GH}$ therapy without notable differences in final height.

While evidence accumulates against the statural advantage of a late onset of puberty, some observations emphasize the need to consider the possible benefits of a relatively early onset of sex steroid treatment. In patients with gonadal dysgenesis, the growth response to sex steroid therapy is greater before $10 \mathrm{yr}$ of bone age; in hypopituitary girls, estrogen therapy starting at $10-11 \mathrm{yr}$ of bone age may be required in order to obtain a full pubertal growth spurt. However, the early induction of sex steroid therapy warrants further studies, particularly regarding dosage, before recommendations for such an approach become acceptable and widespread. Prospective research protocols employing only minute amounts of sex steroids might be considered in the first decade of life.

B. There is a current trend to use lower replacement doses of sex steroids than in the past to induce optimal pubertal growth and development. In boys, a monthly dosage of $25-50 \mathrm{mg}$ testosterone enanthate should be used for the first year of therapy. In girls, a daily dose of $0.1 \mu \mathrm{g} / \mathrm{kg}$ ethinyl-estradiol or less may be appropriate. Optimal steroid amounts still need to be determined. Alternatively, chronic, intermittent administration of GnRH may induce a physiological increase in endogenous secretion of sex steroids (167). However, such treatment clearly has practical limitations.

C. Since precocious puberty results in reduced adult stature, it is conceivable that the final growth status of those patients might be improved by maximally delaying sexual maturation using superagonists of GnRH (168175). However, advancement in bone age results in a reduction of the pubertal height gain and duration of $\mathrm{GnRH}$ agonist therapy results in a progressive decline of height velocity below the normal prepubertal limits. Therefore, in order to maximize residual growth, the withdrawal of GnRH agonist therapy should not be too late. The markedly reduced rate of bone maturation seen at late bone ages may be favorable to final height as long as a satisfactory linear growth velocity is maintained during agonist therapy. These various aspects of treatment will not be clarified until adult stature of patients with precocious puberty can be related to growth parameters at the beginning and at the end of treatment.

Although very early onset of puberty reduces adult stature, very late onset of puberty does not increase adult height. Therefore, there is no rationale for delaying the onset of spontaneous puberty beyond the normal bone ages in patients with very short stature. In very short pubertal patients with isolated GH deficiency, two preliminary studies $(176,177)$ indicate some improvement of predicted adult height with $\mathrm{GnRH}$ agonist therapy.
However, long term studies are required before such treatment on a widespread basis can be considered.

D. Adult stature is less influenced by pubertal growth than by the height at onset of puberty (92). This finding indicates that prepubertal growth which is predominantly controlled by $\mathrm{GH}$, is critical for adult height. Therefore, early onset of GH therapy and adjustment of GH dosage to obtain a satisfactory prepubertal height velocity may be particularly important for adult height. While interesting data are expected from the widespread use of biosynthetic GH in short children (110, 178-182), such intervention warrants further research to determine the appropriate criteria for treatment and to evaluate long-term effects.

Finally, the behavioral aspects of growth manipulation remain uncharted. The premise of "bigger is better," requires careful scrutiny. The psychological impact of improving stature must be balanced against other effects that therapy and associated laboratory studies may have on a developing mind. The excitement we bring to our patients as clinical endocrinologists must be tempered by the prudence we bring as thoughtful physicians.

\section{Acknowledgments}

I am indebted to my colleagues from the Belgian Study Group for Pediatric Endocrinology for providing contributions of their clinical material. I am particularly grateful to C. Ernould (University of Liège, Liège, Belgium), P. Malvaux and M. Maes (University of Louvain, Brussels, Belgium), M. Vanderschueren-Lodeweyckx (University of Leuven, Leuven, Belgium), and M. Vandeweghe (University of Gent, Gent, Belgium) for helpful discussions. I wish to thank H. E. Kulin from the Endocrine Division, The Milton S. Hershey Medical Center of the Pennsylvania State University, College of Medicine (Hershey, PA), J. M. Tanner, from the Institute of Child Health, University of London (London, England), and G. Van Vliet, from the Department of Pediatrics, University of Brussels (Brussels, Belgium), for taking the time to review very pertinently the manuscript. I acknowledge Mrs. B. Bonhomme and Mrs. M. Beyer for their excellent secretarial assistance.

\section{References}

1. Thamdrup E 1961 Precocious Sexual Development: A Clinical Study of Children. Charles C Thomas, Springfield, IL

2. Sigurjonsdottir TJ, Hayles AB 1968 Precocious puberty: a report of 96 cases. Am J Dis Child 115:309

3. Styne DM, Richards GE, Bell JJ, Conte FA, Morishima A, Kaplan SL, Grumbach MM 1975 Growth patterns in congenital adrenal hyperplasia. Correlation of glucocorticoid therapy with stature. In: Lee PA, Plotnick LP, Kowarski AA, Migeon CJ (eds) Congenital Adrenal Hyperplasia. University Park Press, Baltimore, MD, p 247

4. Jones-Klingensmith G, Garcia SC, Jones HW, Migeon CJ, Blizzard RM 1977 Glucocorticoid treatment of girls with congenital adrenal hyperplasia: effects on height, sexual maturation and fertility. J Pediatr 90:996

5. Urban MD, Lee PA, Migeon CJ 1978 Adult height and fertility in men with congenital virilizing adrenal hyperplasia. $\mathrm{N}$ Engl J Med 299:1392

6. Di Martino-Nardi J, Stoner E, O'Connell A, New MI 1986 The effect of treatment on final height in classical congenital adrenal hyperplasia. Acta Endocrinol (Copenh) [Suppl]279:305 
7. Wilkins L 1965 The Diagnosis and Treatment of Endocrine Diseases in Childhood and Adolescence, ed 3. Charles C Thomas Publisher, Springfield, IL

8. Blizzard RM, Thompson RG, Baghdassarian A, Kowarski A, Migeon CJ, Rodriguez A 1974 The interrelationship of steroids, growth hormone and other hormones on pubertal growth. In: Grumbach MM, Grave GD, Mayer FE (eds) The control of the Onset of Puberty. John Wiley \& Sons, New York, p 342

9. Laron Z, Pertzelan A, Mannheimer S 1966 Genetic pituitary dwarfism with high serum concentration of GH. A new inborn error of metabolism. Israel J Med Sci 2:152

10. Laron Z, Sarel R, Pertzelan A 1980 Puberty in Laron type dwarfism. Eur $\mathrm{J}$ Pediatr 134:79

11. Corvol MT, Carrascosa A, Tsagris L, Blanchard O, Rappaport R 1987 Evidence for a direct in vitro action of sex steroids on rabbit cartilage cells during skeletal growth: Influence of age and sex. Endocrinology 120:1422

12. Sizonenko PC, Paunier L 1975 Hormonal changes in puberty. III. Correlation of plasma dehydroepiandrosterone, testosterone, $\mathrm{FSH}$ and LH with stages of puberty and bone age in normal boys and girls and in patients with Addison's disease or hypogonadism or premature or late adrenarche. J Clin Endocrinol Metab 41:894

13. Ducharme JR, Forest MG, De Peretti E, Sempe M, Collu R, Bertrand J 1976 Plasma adrenal and gonadal sex steroids in human pubertal development. J Clin Endocrinol Metab 42:468

14. Lee PA, Migeon CJ 1975 Puberty in boys: correlation of plasma levels of gonadotropins ( $\mathrm{LH}, \mathrm{FSH}$ ), androgens (testosterone, androstenedione, dehydroepiandrosterone and its sulfate), estrogens (estrone and estradiol) and progestins (progesterone and 17hydroxyprogesterone). J Clin Endocrinol Metab 41:556

15. Sizonenko PC 1978 Endocrinology in preadolescents and adolescents. I. Hormonal changes during normal puberty. Am J Dis Child 132:704

16. Apter D 1980 Serum steroids and pituitary hormones in female puberty: a partly longitudinal study. Clin Endocrinol (Oxf) 12:107

17. Ilondo MM, Vanderschueren-Lodeweyckx M, Vlietinck R, Pizzaro M, Malvaux P, Eggermont E, Eeckels R 1982 Plasma androgens in children and adolescents. I. Control subjects. Hormone Res $16: 61$

18. Tanner JM, Davies PSW 1985 Clinical longitudinal standards for height and height velocity for North American Children. J Pediatr 107:317

19. Longcope C, Pratt JH, Schneider SH, Fineberg SE 1978 Aromatization of androgens by muscle and adipose tissue in vivo. $\mathrm{J}$ Clin Endocrinol Metab 46:146

20. MacDonald PC, Madden JD, Brenner PF, Wilson JD, Siiteri PK 1979 Origin of estrogen in normal men and in women with testicular feminization. J Clin Endocrinol Metab 49:905

21. Weinstein RL, Kelch RP, Jenner MR, Kaplan SL, Grumbach MM 1974 Secretion of unconjugated androgens and estrogens by the normal and abnormal human testes before and after human chorionic gonadotropin. J Clin Invest 53:1

22. Frisch RE, Canick JA, Tulchinsky D 1980 Human fatty marrow aromatizes androgen to estrogen. J Clin Endocrinol Metab 51:394

23. Komm BS, Terpening CM, Benz DJ, Graeme KA, Gallegos A, Korc M, Greene GL, O'Malley BW, Haussler MR 1988 Estrogen binding, receptor mRNA, and biologic response in osteoblast-like osteosarcoma cells. Science 241:81

24. Eriksen EF, Colvard DS, Berg NJ, Graham ML, Mann KG, Spelsberg TC, Riggs BL 1988 Evidence of estrogen receptors in normal human osteoblast-like cells. Science 241:84

25. Ho KY, Evans WS, Blizzard RM, Veldhuis JD, Merriam GR, Samojlik E, Furlanetto R, Rogol AD, Kaiser DL, Thorner MO 1987 Effects of sex and age on the twenty-four-hour profile of growth hormone secretion in man: importance of endogenous estradiol concentrations. J Clin Endocrinol Metab 64:51

26. Thompson RG, Rodriguez A, Kowarski A, Migeon CJ, Blizzard RM 1972 Integrated concentrations of growth hormone correlated with plasma testosterone and bone age in pre-adolescent and adolescent males. J Clin Endocrinol Metab 35:344

27. Butenandt O, Eder R, Wohlfarth K, Bidlingmaier F, Knorr D 1976 Mean 24 hour growth hormone and testosterone concentra- tions in relation to pubertal growth spurt in boys with normal or delayed puberty. Eur J Pediatr 122:85

28. Rosenfield RL, Furlanetto R, Bock D 1983 Relationship of somatomedin- $\mathrm{C}$ concentrations to pubertal changes. J Pediatr 103:723

29. Caruso-Nicoletti M, Cassorla FG, Skerda MC, Ross JL, Loriaux DL, Cutler GB 1985 Short-term low dose estradiol accelerates ulnar growth in boys. J Clin Endocrinol Metab 61:896

30. Cassorla FG, Skerda MC, Valk IM, Hung W, Cutler GB, Loriaux DL 1984 The effect of sex steroids on ulnar growth during adolescence. J Clin Endocrinol Metab 58:717

31. Zachmann M, Prader A, Sobel EH, Crigler JF, Ritzen EM, Atares M, Ferrandez A 1986 Pubertal growth in patients with androgen insensitivity: indirect evidence for the importance of estrogens in pubertal growth of girls. J Pediatr 108:694

32. Kulin HE, Coen P, Santen RJ, Ballantine T, Zaino R, Boal D, Inkster S, Brodie A, Gynecomastia in the Peutz-Jeghers syndrome is caused by testicular tumor aromatase production. Pediatr Res, in press (abstract)

33. Hemsell DL, Edman CD, Marks JF, Siiteri PK, MacDonald PC 1977 Massive extraglandular aromatization of plasma androstenedione resulting in feminization of a prepubertal boy. $J$ Clin Invest $60: 455$

34. Rosenfield RL 1986 Low-dose testosterone effect on somatic growth. Pediatrics 77:853

35. Rosenfeld RG, Hintz RL, Johanson AJ, Brasel JA, Burstein S, Chernausek SD, Clabots T, Frane J, Gotlin RW, Kuntze J, Lippe BM, Mahoney PC, Moore WV, New MI, Saenger P, Stoner E, Sybert V 1986 Methionyl human growth hormone and oxandrolone in Turner syndrome: preliminary results of a prospective randomized trial. J Pediatr 109:936

36. Massarano A, Pringle PJ, Hindmarsh 'PC, Stanhope R, Preece MA, Brook CGD 198824 Hour growth hormone profiles in Turner syndrome and the effects of oxandrolone. Pediatr Res 23:127 (Abstract)

37. Rolland A, Job JC 1984 Traitement du nanisme hypophysaire: faut-il traiter le déficit des androgènes surrénaux? Arch Fr Pediatr 41:381

38. Plotnick LP, Thompson RG, Beitins I, Blizzard RM 1974 Integrated concentrations of growth hormone correlated with stage of puberty and estrogen levels in girls. J Clin Endocrinol Metab $38: 436$

39. Link K, Blizzard RM, Evans WS, Kaiser DL, Parker MW, Rogol AD 1986 The effect of androgens on the pulsatile release and the twenty-four-hour mean concentration of growth hormone in peripubertal males. J Clin Endocrinol Metab 62:159

40. Stanhope R, Buchanan CR, Fenn GC, Preece MA 1988 Double blind placebo controlled trial of low dose oxandrolone in the treatment of boys with constitutional delay of growth and puberty. Arch Dis Child 63:501

41. Clayton PE, Shalet SM, Price DA, Addison GM 1988 Growth and growth hormone responses to oxandrolone in boys with constitutional delay of growth and puberty. Clin Endocrinol (Oxf) 29:123

42. Kelch RP, Markovs M, Huss J $1976 \mathrm{LH}$ and FSH responsiveness to intravenous gonadotropin-releasing hormone $(\mathrm{GnRH})$ in children with hypothalamic or pituitary disorders: lack of effect of replacement therapy with human growth hormone. J Clin Endocrinol Metab 42:1104

43. Rivarola MA, Heinrich JJ, Podesta EJ, De Chwojnik MF, Bergada C 1972 Testicular function in hypopituitarism. Pediatr Res 6:634

44. Zachmann M 1972 The evaluation of testicular endocrine function before and in puberty. Acta Endocrinol (Copenh) [Suppl] 164:1

45. Zipf WB, Kelch RP, Hopwood NJ 1982 Testicular responsiveness to human chorionic gonadotrophin in growth hormone-deficient prepubertal boys: lack of effect of replacement therapy. Int $\mathbf{J}$ Androl 5:185

46. Maes M, Wolter R, Vanderschueren M 1984 Effects of human growth hormone and gonadotropins on the testicular response to human chorionic gonadotropin in prepubertal GH-deficient children. Pediatr Res 18:1220 (Abstract)

47. Kulin HE, Samojlik E, Santen R, Santner S 1981 The effect of growth hormone on the Leydig cell response to chorionic gona- 
dotrophin in boys with hypopituitarism. Clin Endocrinol (Oxf) 15:463

48. Kulin HE, Samojlik E, Demers LM, Santner SJ 1985 Response of the prepubertal ovary to acute chorionic gonadotropin administration: absence of modulation by growth hormone. $J$ Clin Endocrinol Metab 60:208

49. Laron Z, Sarel R 1970 Penis and testicular size in patients with GH deficiency. Acta Endocrinol (Copenh) 63:625

50. Goodman HG, Grumbach MM, Kaplan SL 1968 Growth and growth hormone II. A comparison of isolated growth hormone deficiency and multiple pituitary hormone deficiencies in 35 patients with idiopathic hypopituitary dwarfism. N Engl J Med 278:57

51. Hsu CJ, Hammond JM 1987 Gonadotropins and estradiol stimulate the secretion of insulin-like growth factor I by porcine granulosa cells in culture. Endocrinology 120:198

52. Voutilainen R, Miller WL 1987 Coordinate tropic hormone regulation of mRNAs for insulin-like growth factor II and the cholesterol side-chain-cleavage enzyme, P450SSC, in human steroidogenic tissues. Proc Natl Acad Sci USA 84:1590

53. Chatelain $P 1988$ Paracrine role of insulin-like growth factor-I in tissue maturation. Acta Paediatr Scand [Suppl] 343

54. Hsu CJ, Hammond JM 1987 Concomitant effects of growth hormone on secretion of insulin-like growth factor I and progesterone by cultured porcine granulosa cells. Endocrinology 121:1343

55. Copeland KC, Paunier L, Sizonenko PC 1977 The secretion of adrenal androgens and growth patterns of patients with hypogonadotropic hypogonadism and idiopathic delayed puberty. J Pediatr 91:985

56. Tanner JM, Whitehouse RH, Hughes PCR, Carter BS 1976 Relative importance of growth hormone and sex steroids for the growth at puberty of trunk length, limb length and muscle width in growth hormone-deficient children. J Pediatr 89:1000

57. Aynsley-Green A, Zachmann M, Prader A 1976 Interrelation of the therapeutic effects of growth hormone and testosterone on growth in hypopituitarism. J Pediatr 89:992

58. Cutler GB, Cassorla FG, Ross JL, Pescovitz OH, Barnes KM, Comite F, Feuillan PP, Laue L, Foster CM, Kenigsberg D, CarusoNicoletti M, Garcia HB, Uriarte M, Hench KD, Skerda MC, Long LM, Loriaux DL 1986 Pubertal growth: physiology and pathophysiology. Recent Prog Horm Res 42:443

59. Van Dop C, Burstein S, Conte FA, Grumbach MM 1987 Isolated gonadotropin deficiency in boys: clinical characteristics and growth. J Pediatr 111:684

60. Martin LG, Clark JW, Connor TB 1968 Growth hormone secretion enhanced by androgens. J Clin Endocrinol Metab 28:425

61. Martin LG, Grossman MS, Connor TB, Levitsky LL, Clark JW, Camitta FD 1979 Effect of androgen on growth hormone secretion and growth in boys with short stature. Acta Endocrinol (Copenh) 91:201

62. Illig R, Prader A 1970 Effect of testosterone on growth hormone secretion in patients with anorchia and delayed puberty. J Clin Endocrinol Metab 30:615

63. Gourmelen M, Pham-Huu-Trung MT, Girard F 1979 Transient partial hGH deficiency in prepubertal children with delay of growth. Pediatr Res 13:221

64. Sperling MA, Kenny FM, Drash AL 1970 Arginine-induced growth hormone response in children: effect of age and puberty. J Pediatr 77:462

65. Frasier SD, Hilburn JM, Smith FG 1970 Effect of adolescence on the serum growth hormone response to hypoglycemia. J Pediatr $77: 465$

66. Von Puttkamer K, Bierich JR, Brugger F 1977 Östrogentherapie bei Mädchen mit konstitutionellem Hochwuchs. Dtsch Med Wochenschr 102:983

67. Merimee TJ, Fineberg SE 1971 Studies of the sex based variation of the growth hormone secretion. J Clin Endocrinol Metab 33:896

68. Wiedemann E, Schwartz F, Frantz AG 1976 Acute and chronic estrogen effects upon serum somatomedin activity, growth hormone and prolactin in man. J Clin Endocrinol Metab 42:942

69. Clemmons DR, Underwood LE, Ridgway RC, Kliman B, Kjellberg
RN, Van Wyck JJ 1980 Estradiol treatment of acromegaly: reduction of immunoreactive somatomedin- $\mathrm{C}$ and improvement in metabolic status. Am J Med 69:571

70. Meyer WJ, Furlanetto RW, Walker PA 1982 The effect of sex steroids on radioimmunoassayable plasma somatomedin-C concentrations. J Clin Endocrinol Metab 55:1184

71. Moll G, Rosenfield RL, Fang VS 1986 Administration of low-dose estrogen rapidly and directly stimulates growth hormone production. Am J Dis Child 140:124

72. Finkelstein J, Roffwarg HP, Boyar RM, Krema J, Hellman L 1972 Age-related change in the twenty-four-hour spontaneous secretion of growth hormone. J Clin Endocrinol Metab 35:665

73. Plotnik LP, Thompson RG, Kowarski A, Delacerda L, Migeon CJ, Blizzard RM 1975 Circadian variation of integrated concentration of growth hormone in children and adults. J Clin Endocrinol Metab 40:240

74. Miller JD, Tannenbaum GS, Colle E, Guyda HJ 1982 Daytime pulsatile growth hormone secretion during childhood and adolescence. J Clin Endocrinol Metab 55:989

75. Zadik Z, Chalew SA, McCarter RJ, Meistas M, Kowarski AA 1985 The influence of age on the twenty-four-hour integrated concentration of growth hormone in normal individuals. J Clin Endocrinol Metab 60:513

76. Ross JL, Pescovitz OH, Barnes K, Loriaux DL, Cutler GB 1987 Growth hormone secretory dynamics in children with precocious puberty. J Pediatr 110:369

77. Harris DA, Van Vliet G, Egli CA, Grumbach MM, Kaplan SL, Styne DM, Vainsel M 1985 Somatomedin-C in normal puberty and in true precocious puberty before and after treatment with a potent luteinizing hormone-releasing hormone agonist. J Clin Endocrinol Metab 61:159

78. Thompson RG, Plotnick L, Kowarski AA, Blizzard RM 1973 The pubertal growth spurt: role of human growth hormone. In: Raiti $\mathrm{S}$ (ed) Advances in Human Growth Hormone Research. DHEW publication (NIH) 74:612 US Government printing office, Washington DC, p 670

79. Liu L, Merriam GR, Sherins RJ 1987 Chronic sex steroid exposure increases mean plasma growth hormone concentration and pulse amplitude in men with hypogonadotropic hypogonadism. $\mathbf{J}$ Clin Endocrinol Metab 64:651

80. Mauras N, Blizzard RM, Link K, Johnson ML, Rogol AD, Veldhuis JD 1987 Augmentation of growth hormone secretion during puberty: evidence for a pulse amplitude-modulated phenomenon. J Clin Endocrinol Metab 64:596

81. Spiliotis BE, August GP, Hung W, Sonis W, Mendelson W, Bercu BB 1984 Growth hormone neurosecretory dysfunction: a treatable cause of short stature. JAMA 251:2223

82. Drop SL, Sarbe-Claus L, Visser HK 1982 The effect of puberty and short-term oral administration of testosterone undecanoate on GH tests and sex-steroid related plasma compounds in GH deficient patients. Clin Endocrinol (Oxf) 16:375

83. Brasel JA, Wright JC, Wilkins L, Blizzard RM 1965 Evaluation of seventy five patients with hypopituitarism beginning in childhood. Am J Med 38:484

84. Rimoin DL, Merimee TJ, McKusick VA 1966 Growth-hormone deficiency in man: isolated recessively inherited defect. Science 152:1635

85. Burns EC, Tanner JM, Preece MA, Cameron N 1981 Final height and pubertal development in 55 children with idiopathic growth hormone deficiency, treated for between 2 and 15 years with human growth hormone. Eur J Pediatr 137:155

86. Bourguignon JP, Vandeweghe M, Vanderschueren-Lodeweyckx M, Malvaux P, Wolter R, Du Caju M, Ernould C 1986 Pubertal growth and final height in hypopituitary boys: a minor role of bone age at onset of puberty. J Clin Endocrinol Metab 63:376

87. Ranke MB, Butenandt 01988 Idiopathic growth hormone deficiency: final height to treatment with growth hormone and effects of puberty and sex steroids. In: Frisch H, Laron Z (eds) Induction of Puberty in Hypopituitarism. Serono symposia review 16, ArisSerono Symposia, Rome, p 85

88. Pertzelan A, Adler-Bier M, Kauli R, Josefsberg Z, Grunebaum M, Horodniceanu CH, Laron Z 1979 Linear growth in hypopituitary 
patients treated with hGH after age fifteen. Acta Paediatr Scand [Suppl] 277:69

89. Lenko HL, Leisti S, Perheentupa J 1982 The efficacy of growth hormone in different types of growth failure. An analysis of 101 cases. Eur J Pediatr 138:241

90. Joss E, Zuppinger K, Schwarz HP, Roten H 1983 Final height of patients with pituitary growth failure and changes in growth variables after long term hormonal therapy. Pediatr Res 17:676

91. Tanner J, Whitehouse RH, Takaishi M 1966 Standards from birth to maturity for height, weight, height velocity and weight velocity: British children 1965. Arch Dis Child 41:454

92. Tanner JM, Whitehouse RH, Marubini E, Resele LF 1976 The adolescent growth spurt of boys and girls of the Harpenden growth study. Ann Hum Biol 3:109

93. Job JC, Chaussain JL, Garnier P, Rolland A, Joab N 1987 Doseresponse relationship in the treatment of hypopituitary children with human growth hormone: a retrospective survey. Acta Paediatr Scand [Suppl] 337:93

94. Preece MA, Tanner JM, Whitehouse RH, Cameron N 1976 Dose dependence of growth response to human growth hormone in growth hormone deficiency. J Clin Endocrinol Metab 42:477

95. Frasier SD, Costin G, Lippe BM, Aceto T, Bunger PF 1981 A dose-response curve for human growth hormone. J Clin Endocrinol Metab 53:1213

96. Salmon WD, Daughaday WH 1957 A hormonally controlled factor which stimulates sulfate incorporation by cartilage in vitro. $\mathrm{J} \mathrm{Lab}$ Clin Med 49:825

97. Van Wyk JJ, Underwood LE, Hintz RL, Clemmons Dr, Voina SJ, Weaver RP 1974 The somatomedins: a family of insulin-like hormones under growth hormone control. Recent Prog Horm Res $30: 259$

98. Daughaday WH 1983 The somatomedin hypothesis: origins and recent development. In: Spencer EM (ed) Insulin-Like Growth Factors/Somatomedins. Walter de Gruyter \& Co, Berlin, p 3

99. Froesch ER 1983 From NSILA to IGF: a look back on the major advances and breakthroughs. In: Spencer EM (ed) Insulin-Like Growth Factors/Somatomedins. Walter de Gruyter \& Co, Berlin, p 13

100. D'Ercole AJ, Stiles AD, Underwood LE 1984 Tissue concentration of somatomedin-C: further evidence for multiple sites of synthesis and paracrine or autocrine mechanisms of action. Proc Natl Acad Sci USA 81:935

101. D'Ercole AJ, Han VKM, Lund PK, Paracrine/autocrine roles for somatomedins/insulin-like growth factors: evidence derived from the fetus. Program of the 69th Annual Meeting of The Endocrine Society, Indianapolis, IN, 1987, p 16

102. Atkison PR, Weidman ER, Bhaumick B, Bala RM 1980 Release of somatomedin-like activity by cultured WI-38 human fibroblasts. Endocrinology 106:2006

103. Clemmons DR, Underwood LE, Van Wyk JJ 1981 Hormonal control of immunoreactive somatomedin production by cultured human fibroblasts. J Clin Invest 67:10

104. Isaksson OGP, Jansson JO, Gause IAM 1982 Growth hormone stimulates longitudinal bone growth directly. Science 216:1237

105. Isaksson OGP, Lindahl A, Nilsson A, Isgaard J 1987 Mechanism of the stimulatory effect of growth hormone on longitudinal bone growth. Endocr Rev 8:426

106. Hintz RL, Liu F, Rosenfeld RG, Kemp SF 1981 Plasma somatomedin binding proteins in hypopituitarism: changes during growth hormone therapy. J Clin Endocrinol Metab 53:100

107. Hall K, Lundin L, Povoa G 1988 Serum levels of the low molecular weight form of insulin-like growth factor binding protein in healthy subjects and patients with growth hormone deficiency, acromegaly and anorexia nervosa. Acta Endocrinol (Copenh) 118:321

108. Copeland KC, Underwood LE, Van Wyk JJ 1980 Induction of immunoreactive somatomedin $\mathrm{C}$ in human serum by growth hormone: dose-response relationship and effect of chromatographic profiles. J Clin Endocrinol Metab 50:690

109. Rosenfeld RG, Kemp SF, Hintz RL 1981 Constancy of somatomedin response to growth hormone treatment of hypopituitary dwarfism and lack of correlation with growth rate. J Clin Endocrinol Metab 53:611

110. Van Vliet G, Styne DM, Kaplan S, Grumbach MM 1983 Growth hormone treatment for short stature. N Engl J Med 309:1016

111. Rosenfield RL, Furlanetto R 1985 Physiologic testosterone or estradiol induction of puberty increases plasma somatomedin-C. J Pediatr 107:415

112. Cara JF, Rosenfield RL, Furlanetto RW 1987 A longitudinal study of the relationship of plasma somatomedin-C concentration to the pubertal growth spurt. Am J Dis Child 141:562

113. Mansfield MJ, Rudlin CR, Crigler JF, Karol KA, Crawford JD, Boepple PA, Crowley WF 1988 Changes in growth and serum growth hormone and plasma somatomedin-C levels during suppression of gonadal sex steroid secretion in girls with central precocious puberty. J Clin Endocrinol Metab 66:3

114. Rappaport R, Prevot C, Brauner R 1987 Somatomedin-C and growth in children with precocious puberty: a study of the effect of the level of growth hormone secretion. J Clin Endocrinol Metab 65:1112

115. Luna AM, Wilson DM, Wibbelsmann CJ, Brown RC, Nagashima RJ, Hintz RL, Rosenfeld RG 1983 Somatomedins in adolescence: a cross-sectional study of the effect of puberty on plasma insulinlike growth factor I and II levels. J Clin Endocrinol Metab 57:268

116. Bala RM, Lopatka J, Leung A, McCoy E, McArthur RG 1981 Serum immunoreactive somatomedin levels in normal adults, pregnant women at terrn, children at various ages and children with constitutionally delayed growth. J Clin Endocrinol Metab 52:508

117. Underwood LE, D'Ercole AJ, Van Wyk JJ 1980 Somatomedin-C and assessment of growth. Pediatr Clin North Am 27:771

118. Parker MW, Johanson AJ, Rogol AD, Kaiser DL, Blizzard RM 1984 Effects of testosterone on somatomedin-C concentrations in prepubertal boys. J Clin Endocrinol Metab 58:87

119. Rosenfield RL, Fang VS 1974 The effects of prolonged physiologic estradiol therapy on the maturation of hypogonadal teen-agers. J Pediatr 85:830

120. Ross JL, Cassorla FG, Skerda MC, Valk IM, Loriaux DL, Cutler GB 1983 A preliminary study of the effect of estrogen dose on growth in Turner's syndrome. N Engl J Med 39:1104

121. Cuttler L, Van Vliet G, Conte FA, Kaplan SL, Grumbach M 1985 Somatomedin-C levels in children and adolescents with gonadal dysgenesis: differences from age-matched normal females and effect of chronic replacement therapy. J Clin Endocrinol Metab 60:1087

122. Craft WH, Underwood LE 1984 Effect of androgens on plasma somatomedin-C/insulin-like growth factor I. Responses to growth hormone. Clin Endocrinol (Oxf) 20:549

123. Ross JL, Long LM, Skerda M, Cassorla F, Kurtz D, Loriaux DL, Cutler GB 1986 Effects of low doses of estradiol on 6-month growth rates and predicted height in patients with Turner syndrome. J Pediatr 109:950

124. Martinez A, Heinrich JJ, Domene H, Escobar ME, Jasper H, Montuori JE, Bergada C 1987 Growth in Turner's syndrome: long-term treatment with low dose ethinylestradiol. J Clin Endocrinol Metab 65:253

125. Merimee TJ, Zapf J, Froesch ER 1981 Dwarfism in the pygmy: an isolated deficiency of insulin-like growth factor I. N Engl J Med 305:965

126. Merimee TJ, Zapf J, Hewlett B, Cavalli-Sforza LL 1987 Insulinlike growth factors in pygmies. The role of puberty in determining final stature. N Engl J Med 316:906

127. Van De Koppel J, Hewlett B 1985 Growth of Aka pygmies and Bagandus of the central African Republic. In: Cavalli-Sforza LL (ed) African Pygmies. Academic Press, New York, p 95

128. Ranke MB, Blum WPF, Haug F, Bierich JR 1988 Somatomedins and growth hormone secretion in Ullrich-Turner syndrome. Pediat Res 23:127 (Abstract)

129. Bierich JR 1978 Estrogen treatment of girls with constitutional tall stature. Pediatrics [Suppl] 62:1196

130. Molinari L, Largo RH, Prader A 1980 Analysis of growth spurt at age seven (mid-growth spurt). Helv Paediatr Acta 35:325

131. Forest MG, De Peretti E, David M, Sempe M 1982 L'adrénarche 
joue-t-elle vraiment un röle déterminant dans le développement pubertaire? Etude des dissociations entre adrénarche et gonadarche. Echec du traitement par la déhydroépiandrostérone sulfate dans les retards d'adrénarche. Ann Endocrinol (Paris) 43:465

132. Craen M, Du Caju MVL, Bourguignon JP, Ernould C, Malvaux $\mathrm{P}$, Vandeweghe $\mathrm{M}$, Wolter $\mathrm{R}$, Vanderschueren-Lodeweyckx $\mathrm{M}$ 1982 Effects of oral treatment with DHEA-S in girls with hypopituitarism. Pediatr Res 16:888 (Abstract)

133. Sizonenko PC, Paunier L 1987 Failure of dehydroepiandrosterone enanthate to promote growth. J Clin Endocrinol Metab 62:1322

134. Bourguignon JP 1988 Variations in duration of pubertal growth: a mechanism compensating for differences in timing of puberty and minimizing their effects on final height. Acta Paediatr Scand, [Suppl] 343

135. Zachmann M, Sobradillo B, Frank M, Frisch H, Prader A 1978 Bayley-Pinneau, Roche-Wainer-Thissen, and Tanner Height predictions in normal children and in patients with various pathologic conditions. J Pediatr 93:749

136. Bayley N, Pinneau SR 1952 Tables for predicting adult height from skeletal age: revised for use with the Greulich-Pyle hand standards. J Pediatr 40:423

137. Greulich WW, Pyle SI 1959 Radiographic Atlas of Skeletal Development of the Hand and Wrist, ed 2. Stanford University Press, Stanford, CA

138. Tanner JM, Whitehouse RH, Cameron N, Marshall WA, Healy MJR, Goldstein H 1983 Assessment of Skeletal Maturity and Prediction of Adult Height (TW2 Method), ed 2. Academic Press, London

139. Burns EC, Tanner JM, Preece MA, Cameron N 1981 Growth hormone treatment in children with craniopharyngioma: final growth status. Clin Endocrinol (Oxf) 14:587

140. Rolland A, Mugnier E, Rappaport R, Job JC 1980 Le traitement du nanisme hypophysaire par l'hormone de croissance humaine. Résultats avant et pendant la puberté. Arch Fr Pediatr 37:659

141. Lev-Ran A 1977 Androgens, estrogens and the ultimate height in XO gonadal dysgenesis. Am J Dis Child 131:648

142. Lucky AW, Marynick SP, Rebar RW, Cutler GB, Glen M, Johnsonbaugh RE, Loriaux DL 1979 Replacement oral ethinyloestradiol therapy for gonadal dysgenesis: growth and adrenal androgen studies. Acta Endocrinol (Copenh) 91:519

143. Demetriou E, Emans J, Crigler JF 1984 Final height in estrogentreated patients with Turner syndrome. Obstet Gynecol 64:459

144. Ranke MB, Haug F, Blum WF, Rosendahl W, Attanasio A, Bierich JR 1986 Effect on growth of patients with Turner's syndrome treated with low estrogen doses. Acta Endocrinol (Copenh) [Suppl] 279:153

145. Kastrup KW, Jacobsen BB, Lebech PE, Peitersen B, Petersen KE, Thamdrup E, Wichmann R 1986 Growth and development in girls with Turner's syndrome during early therapy with low doses of estradiol. Acta Endocrinol (Copenh) [Suppl] 279:157

146. Prader A, Zachmann M 1978 Treatment of excessively tall girls and boys with sex hormones. Pediatrics [Suppl] 62:1202

147. Crawford JD 1978 Treatment of tall girls with estrogens. Pediatrics $62: 1189$

148. Conte FA, Grumbach MM 1978 Estrogen use in children and adolescents: a survey. Pediatrics 62:1091

149. Bartsch O, Weschke B, Weber B 1988 Oestrogen treatment of constitutionally tall girls with $0.1 \mathrm{mg} /$ day ethinyl oestradiol. Eur J Pediatr 147:59

150. Buckler JMH 1984 Skeletal age changes in puberty. Arch Dis Child 59:115

151. Zachmann M, Ferrandez A, Mürset G, Prader A 1976 Testosterone treatment of excessively tall boys. J Pediatr 88:116

152. Brook CGD, Murset G, Zachmann M, Prader A 1974 Growth in children with 45,XO Turner's syndrome. Arch Dis Child 49:789

153. Ranke MB, Pfluger $H$, Rosendahl W, Stubbe P, Enders H, Bierich JR, Majewski F 1983 Turner syndrome: spontaneous growth in 150 cases and review of the literature. Eur J Pediatr 141:81

154. Raiti S, Moore WV, Van Vliet G, Kaplan S 1986 Growth-stimulating effects of human growth hormone therapy in patients with Turner syndrome. J Pediatr 109:944

155. Bourguignon JP, Heinrichs C, Van Vliet G, Vandeweghe $M$,
Vanderschueren-Lodeweyckx M, Malvaux P, Du Caju M, Craen M, Lambrechts L, Delire M, Ernould C 1987 Evaluation and significance of the degree of pituitary-gonadal inhibition during intranasal administration of buserelin. Acta Endocrinol (Copenh) 116:519

156. Boepple PA, Mansfield MJ, Crawford JD, Crigler JF, Link K, Blizzard RM, Crowley WF, The effects of gonadal sex steroids and their reversible suppression on statural growth and skeletal maturation in girls with central precocious puberty. In: Grave GD, Cassorla F (eds) Disorders of Human Growth: Advances in Research and Treatment. Charles C Thomas, Springfield, IL, in press

157. Boas F 1932 Studies in growth. Hum Biol 4:307

158. Karlberg J, Fryer JG, Engström I, Karlberg P 1987 Analysis of linear growth using a mathematical model. II. From 3 to 21 years of age. Acta Paediatr Scand [Suppl] 337:12

159. Zachmann M, Prader A 1970 Anabolic and androgenic effect of testosterone in sexually immature boys and its dependency on growth hormone. J Clin Endocrinol Metab 30:85

160. Kaplan JG, Moshang T, Bernstein R, Parks JS, Bongiovanni AM 1973 Constitutional delay of growth and development: effects of treatment with androgens. J Pediatr 82:38

161. Martin MM, Martin ALA, Mossman KL 1986 Testosterone treatment of constitutional delay in growth and development: effect of dose on predicted versus definitive height. Acta Endocrinol (Copenh) [Suppl] 279:147

162. Rochiccioli P, Tock Mine YY, Enjaume C, Dutau G, Sablayrolles B 1985 Le retard de maturation osseuse est un elément favorable du pronostic de la taille définitive. Arch Fr Pediatr 42:273

163. Zachmann M, Studer S, Prader A 1987 Short-term testosterone treatment at bone age of 12 to 13 years does not reduce adult height in boys with constitutional delay of growth and adolescence. Helv Paediatr Acta 42:21

164. Prader A 1984 Croissance pubertaire et taille définitive. Réflexions sur nos conduites thérapeutiques. In: Tenth séminaire d'Endocrinologie Pédiatrique et de Diabétologie, Hôpital des Enfants Malades, Paris, p 74

165. Largo RH, Gasser T, Prader A 1978 Analysis of the adolescent growth spurt using smoothing spline functions. Ann Hum Biol $5: 421$

166. Ehrhardt AA, Meyer-Bahlburg HFL 1975 Psychological correlates of abnormal pubertal development. Clin Endocrinol Metab 4:207

167. Stanhope R, Pringle PJ, Brook CGD 1988 The mechanism of the adolescent growth spurt induced by low dose pulsatile $\mathrm{GnRH}$ treatment. Clin Endocrinol (Oxf) 28:83

168. Styne DM, Harris DA, Egli CA, Conte FA, Kaplan SL, Rivier J, Vale W, Grumbach MM 1985 Treatment of true precocious puberty with a potent luteinizing hormone-releasing factor agonist: effect on growth, sexual maturation, pelvic sonography and the hypothalamic-pituitary-gonadal axis. J Clin Endocrinol Metab 61:142

169. Brauner R, Thibaud E, Bischof P, Sizonenko PC, Rappaport R 1985 Long-term results of $\mathrm{GnRH}$ analogue (Buserelin) treatment in girls with central precocious puberty. Acta Paediatr Scand 74:945

170. Pescovitz OA, Comite F, Hench K, Barnes K, McNemar A, Foster C, Kenigsberg D, Loriaux DL, Cutler GB 1986 The NIH experience with precocious puberty: diagnostic subgroups and response to short-term luteinizing hormone releasing hormone analogue therapy. J Pediatr 108:47

171. Boepple PA, Mansfield MJ, Wierman ME, Rudlin CR, Bode HH, Crigler JF, Crawford JD, Crowley WF 1986 Use of a potent, long acting agonist of gonadotropin-releasing hormone in the treatment of precocious puberty. Endocr Rev 7:24

172. Mansfield MJ, Beardsworth DE, Loughlin JS, Crawford JD, Bode HH, Rivier J, Vale W, Kushner DC, Crigler JF, Crowley WF 1983 Long-term treatment of central precocious puberty with a longacting analogue of luteinizing hormone-releasing hormone. Effects on somatic growth and skeletal maturation. N Engl J Med 309:1286

173. Roger M, Chaussain JL, Berlier P, Bost M, Canlorbe P, Colle M, François R, Garandeau P, Lahlou N, Morel Y, Schally AV 1986 
Long term treatment of male and female precocious puberty by periodic administration of a long-acting preparation of D-TRP6Luteinizing hormone-releasing hormone microcapsules. J Clin Endocrinol Metab 62:670

174. Drop SLD, Oding RJH, Rouwe C, Otten BJ, Van Maarschalkerneerd MW, Gons M, Bot A, Meradji M, De Jong FH, Slijper FME 1987 The effect of treatment with a LH-RH agonist (Buserelin) on gonadal activity, growth and bone maturation in children with central precocious puberty. Eur J Pediatr 146:272

175. Bourguignon JP, Van Vliet G, Vandeweghe M, Malvaux P, Vanderschueren-Lodeweyckx M, Craen M, Du Caju MVL, Ernould C 1987 The treatment of central precocious puberty with an intranasal analogue of GnRH (Buserelin). Eur J Pediatr 146:555

176. Toublanc JE, Garnier P, Couprie C, Chaussain JL, Job JC 1988 Effect of LHRH analogue in pubertal patients with isolated growth hormone deficiency. Pediatr Res 23:121 (Abstract)

177. Konitsiotou D, Pantsiotou K, Andrianos C, Dacou-Voutetakis C 1988 LHRH analog administration to pubertal children with isolated GH deficiency. Pediatr Res 23:121 (Abstract)
178. Rudman D, Kutner MH, Blackston RD, Cushman RA, Bain RP, Patterson JH 1981 Children with normal variant short stature: treatment with human growth hormone for six months. N Engl J Med 305:123

179. Gertner JM, Genel M, Gianfredi SP, Hintz RL, Rosenfeld RG, Tamborlan WV, Wilson DM 1984 Prospective clinical trial of human growth hormone in short children without growth hormone deficiency. J Pediatr 104:172

180. Chalew SA, Raiti S, Armour KM, Kowarski A 1987 Therapy in short children with subnormal integrated concentrations of growth hormone. Am J Dis Child 141:1195

181. Albertson-Wikland K, Hall K 1987 Growth hormone treatment in short children: relationship between growth and serum insulinlike growth factor I and II levels. J Clin Endocrinol Metab 65:671

182. Raiti S, Kaplan SL, Van Vliet G, Moore WV 1987 Short-term treatment of short stature and subnormal growth rate with human growth hormone. J Pediatr 110:357

183. MacDonald PC, Edman CD, Kerber IJ, Siiteri PK 1976 Plasma precursors of estrogen. III. Conversion of dehydroisoandrosterone to estrogen in young nonpregnant women. Gynecol Invest 7:165

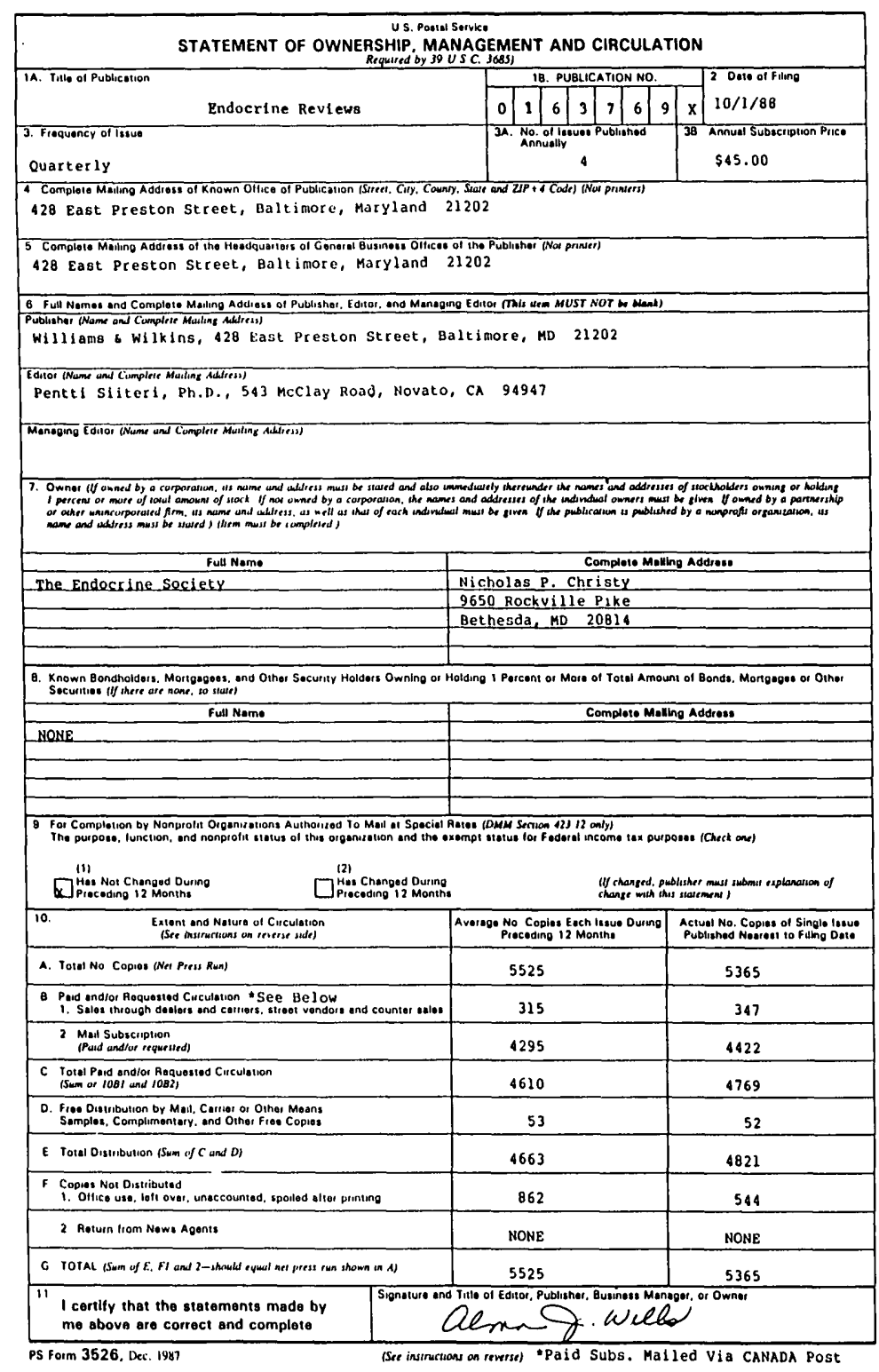

